\title{
Lise Matematik Öğretmenlerinin Türevin Tanımına ve Türev-Süreklilik İlişkisine Yönelik Pedagojik Alan Bilgileri*
}

\author{
High School Teachers' Pedagogical Content Knowledge on Defination of \\ Derivative, and Relationship Between Derivative and Continuity
}

$\mathrm{DOI}=\underline{\underline{10.17556 / j \mathrm{jef} .68600}}$

\author{
Murat DURAN ${ }^{* *}$, Abdullah KAPLAN ${ }^{* * *}$
}

\section{Özet}

$\mathrm{Bu}$ araştırmanın amacı lise matematik öğretmenlerinin türevin tanımına, türevin tanımının görselleştirilmesine ve türev-süreklilik ilişkisine yönelik pedagojik alan bilgilerini konu alanı bilgisi bağlamında incelemektir. Öğretmenlerin konu alanı bilgileri; türevi tanımlama ve örneklendirme, türevin tanımını görselleştirme ve türev-süreklilik arasındaki ilişkiyi açıklama şeklinde üç başlık altında incelenmiştir. Nitel araştırma modellerinden özel durum çalışmasına göre desenlenen bu araştırma 2015-2016 öğretim yılı güz döneminde Karadeniz Bölgesi'ndeki bir şehirde gerçekleştirilmiştir. Araştırmanın katılımcıları ikisi fen edebiyat fakültesi mezunu, diğer ikisi ise eğitim fakültesi mezunu olmak üzere dört lise matematik öğretmenidir. Araştırmanın veri toplama aracı araştırmacılar tarafindan geliştirilmiş yarı yapılandırılmış görüşme formudur. Araştırmanın verileri içerik analizi tekniğiyle incelenmiştir. Araştırmadan elde edilen sonuçlara göre lise matematik öğretmenlerinin türevin tanımına yönelik gerekli ancak yetersiz tanım yaptıkları belirlenmiştir. Öğretmenlerin türev kavramına verdikleri örneklerin anlık değişim, değişim hızı ve değişim oranı gibi prototip örneklerle sınırlandığı görülmüştür. Öğretmenlerden ikisinin türev-süreklilik ilişkisine yönelik yeterli açıklamalarda bulundukları tespit edilirken diğer ikisinin bu ilişkiyi gerekli ancak yetersiz şekilde açıkladıkları sonucuna varılmıştır.

Anahtar Sözcük: Türev, Pedagojik Alan Bilgisi, Konu Alanı Bilgisi

\begin{abstract}
The purpose of this research is to investigate high school mathematics teachers' pedagogical content knowledge in the context of subject matter knowledge

\footnotetext{
${ }^{*} \mathrm{Bu}$ araştrıma birinci yazarın doktora tezi pilot çalışmasında kullanılan verilerin bir bölümünden üretilmiştir. Araştırmada katkısı olan Dr. Muhammet DORUK'a teşekkür ederiz.

*** Doktora Öğrencisi, Atatürk Üniversitesi, Eğitim Bilimleri Enstitüsü, İlköğretim ABD, Matematik Eğitimi Bilim Dalı, Erzurum, Türkiye, denizyildizi2805@hotmail.com

**** Prof. Dr., Atatürk Üniversitesi, Kazım Karabekir Eğitim Fakültesi, İlköğretim Matematik Öğretmenliği Bilim Dalı, Erzurum, Türkiye, akaplan@atauni.edu.tr
} 
on the definition of derivative, the visualization of the definition of derivative, and the relationship between derivative and continuity. The subject matter knowledges of teachers are examined in the form of defining derivatives and giving examples to derivatives from everyday life, visualizing the definition of derivatives and explaining the relationship between derivatives and continuity. The case study design of the qualitative research models is used in this research. The research is carried out in a city of the Black Sea Region of Turkey during the fall semester of 2015-2016 academic terms. The participants of the research are four mathematics teachers two graduated from the faculty of science-letters and the other two graduated from the faculty of education. The data collection tool is a semi-structural interview protocol developed by the researchers. The research data are analyzed by content analysis. According to the results of the research, high school mathematics teachers made necessary but insufficient definitions for the definition of the derivative. The teachers have presented prototype examples such as instant change, rate of change and exchange ratio in relation to the derivative. Two of the teachers were found to have made sufficient explanations for the relationship between the derivative and continuity while the other two explained necessary but inadequately manner for the same relationship. Knowledge

Keywords: Derivatives, Pedagogical Content Knowledge, Subject Matter

\section{Giriş}

Küreselleşen dünyada bilim ve teknoloji alanındaki gelişmeler güncel bilgi ve becerilerle donatılmış, çağın şartlarına ayak uyduran nitelikli bireylerin yetişmesini gerekli kılmıştır (Konyalığlu, 2003). Nitelikli bireylerin yetiştirilmesi ancak nitelikli öğretmenler eliyle gerçekleştirilebilir (Batur \& Balc1, 2013). Öğretmenlerin daha kaliteli yetişebilmesi, öğrenilmesi gereken bilgi ve becerilerin öğretmen adaylarına kazandırılmasıyla mümkün olmaktadır (Erdem, 2005). Etkili bir öğretime yönelik öğretmen yeterlikleri incelendiğinde bu yeterliklerin başında konu alanı bilgisi gelir (Alev \& Karal, 2013). Ayrıca bir kuralı ya da kavramı öğrenme sürecinde bireysel ihtiyaçları da dikkate alarak öğretim gerçekleştirme konusunda pedagoji bilgisi gibi daha farklı bilgi çeşitlerine de ihtiyaç duyulmaktadır (Shulman, 1986). Günümüzde alan bilgisi ile pedagoji bilgisinin bütünleşmesi pedagojik alan bilgisi kavramının önemini arttırmıştır (Gess Newsome, 1999). İlk olarak Shulman (1986) tarafından alanyazına kazandırılan pedagojik alan bilgisi, kalıcı öğrenmeler gerçekleştirmek amacıyla kavramları en doğru temsil eden benzeşimlerin, görsellerin, açıklamaların ve örneklerin kullanılmasını sağlayan bilgi türü olarak tanımlanmıştır. 
Shulman (1987) "öğretmenliğin bilgi temeli" olarak isimlendirdiği modelinde "öğrenciyi anlama" bilgisi ve "öğretim strateji, yöntem ve teknik" bilgisini pedagojik alan bilgisiyle beraber incelerken "konu alanı" bilgisini farklı bir kategoride incelemiştir. Konu alanı bilgisini pedagojik alan bilgisinden farklı değerlendiren Grossman (1990) ise "pedagojik alan bilgisi" boyutunu merkeze alarak bu boyutu "içerik bilgisi", "konu alanı bilgisi", "genel pedagojik bilgi" boyutlarıyla ilişkili şekilde göstermiştir. Marks (1990) ise modelinde konu alanı bilgisiyle pedagojik alan bilgisinin özdeşleşebileceğini ve bu iki kavram arasına engel koymanın doğru olmadığını ifade etmiştir. Veal, Tippins ve Bell (1998)'e göre pedagojik alan bilgisinde başarılı olmanın ilk koşulu iyi düzeyde konu alanı bilgisine sahip olmaktır.

Alanyazındaki araştırmalar, pedagojik alan bilgisiyle konu alanı bilgisinin birbiriyle ilişkili olduğunu (Gökkurt, Şahin \& Soylu, 2012; Halim \& Meerah, 2002; Türnüklü, 2005) ve konu alanı bilgisinin pedagojik alan bilgisi bileşenleri dışında tutulamayacağını göstermiştir (Bennett \& Turner-Bisset, 1993). Konu alanı bilgisi, öğretmenin herhangi bir konudaki tanım, kural, örnek, görsel ve başlık hakkında bilgi sahibi olmasını ifade eder (Canbazoğlu, Demirelli \& Kavak, 2010). Öğretim sürecinde belirlenen etkinliklerin konuya uygunluğu, öğrencilere üretken soruların sorulması, öğrenci anlamalarını değerlendirme gibi öğretim etkinlikleri öğretmenin konu alanı bilgisiyle ilgilidir (Ball \& McDiarmid, 1990). Konu alanı bilgisine yeterince sahip öğretmenler daha güvenilir ders işlemekte, öğretime yönelik çeşitli stratejilere ihtiyaç duymakta ve sorulara tatmin edici cevaplar verip dersi daha zevkli kılmaktadır (Cohen, McLaughlin \& Talbert, 1993). Buna karşın yetersiz konu alan bilgisine sahip öğretmenlerin öğrencilere aktardıkları bilgiler yüzeysel kalırken öğrencilerdeki hataların ve kavram yanılgılarının düzeltilmesi de zorlaşmaktadır (Käpyla, Heikkinen \& Asunta, 2009).

Matematik öğretmenlerinin konu alanı bilgilerine yönelik yapılan çalışmalarda öğretmenlerin, matematiğin çeşitli konularında yetersiz ve hatalı bilgilere sahip oldukları, ayrıca ilgili kavramları öğrencilere yanlış aktardıkları görülmüştür (Hawkins, 2012; Vermette \& Gattuso, 2014; Yılmaz, 2016; Yusof \& Zakaria, 2010). Öğretmenler ve öğretmen adayları konu alanı bilgilerini daha çok işlemsel anlamda 
kullandıklarından kavramsal anlamda sorun yaşamaktadır (Hiebert \& Lefevre, 1986; Skemp, 1978). Bu nedenle bu araştırmada lise matematik öğretmenlerinin türev konusuna yönelik konu alanı bilgileri kavramsal anlamda incelenmiştir. Bir kavramın zihinlerde yanılgıya neden olmaması için öğretim yapacak bireyin ilgili kavrama önce kendisinin hakim olması gerekir (Çakmak, Konyalığlu \& Işık, 2014). Ayrica lisede türev konusunun sağlam bir temele dayandırılarak öğrencilere kavramsal anlamda öğretilmesi gerekmektedir (James, 1995). Çünkü lise düzeyinde kavramsal olarak iyi öğrenilemeyen analiz konuları üniversitenin ilk sınıfındaki öğrenciler için engel olabilmektedir (Burton, 1989). Bundan dolay1, mevcut çalışmada öğretmenlerin kavramı doğru anlaşılacak şekilde tanımlama, kavrama günlük hayattan örnekler verme, kavramın tanımını görselleştirme, görselleştirme sürecini doğru açılama ve kavramlar arası ilişkileri doğru ifade etme gibi davranışları gerçekleştirme durumları dikkate alınmıştır. Alanyazında türeve yönelik çalışmalarda türevin cebirsel tanımı (Zandieh, 1997), türevlimit ilişsisi (Bingölbali, 2013), fonksiyonun türevi ile sürekliliğini anlama (Artigue, 1991; Viveros \& Sacristan, 2002), değişim oran1 kavramını açıklama (Bezuindenhout, 1998; Orton, 1983) gibi konularda öğrencilerin zorluk yaşadıkları ve bazı kavram yanılgılarına sahip oldukları belirtilmektedir.

Pedagojik alan bilgisiyle ilgili olarak üç boyutlu cisimlere (Altayl1, Konyalıŏlu, Hızarcı \& Kaplan, 2014; Çakmak vd., 2014; Gökbulut, 2010), sayı örüntülerine (Yeşildere \& Akkoç, 2010) ve kesirlere (Arslan Kılcan, 2006) yönelik yapılan çalışmalardan elde edilen ortak sonuçlara göre öğretmen adayları kavramları anlarken zorluk yaşamakta ve hatalı tanımlamalar yapmaktadır. $\mathrm{Bu}$ araştırmaların diğer bir ortak yanı ise çalışmaların ortaokul düzeyinde yapılmış olmasıdır. Ortaokul düzeyinde pedagojik alan bilgisine yönelik çalışmalardan elde edilen sonuçlar lise öğretmenlerinin pedagojik alan bilgilerini açıklamada yetersiz kalmaktadır (Käpyla vd., 2009). Bu bağlamda lise matematik öğretmenlerinin matematik dersinde konuya özel pedagojik alan bilgilerini ortaya çıkaracak, alanyazında lise matematik ögretmenleriyle yapılacak durum çalışmalarının niteliğini arttıracak yeni araştırmalara ihtiyaç vardır. 
Bunun yanı sıra alanyazındaki pedagojik alan bilgisi çalışmaları incelendiğinde bu çalışmaların lise matematik öğretmenleriyle değil, çoğunlukla ortaokul matematik öğretmen adaylarıyla yapıldığı görülmüştür (Akkoç, Yeşildere \& Özmantar, 2007; Krauss, Baumert \& Blum, 2008; Gökkurt, Şahin, Soylu \& Doğan, 2015; Lannin, Webb, Chval, Arbaugh, Hicks, Taylor \& Bruton, 2013; Tichá \& Hošpesová, 2010). Matematik öğretmen adaylarından elde edilen bilgiler lise matematik öğretmenlerinin konuya dönük pedagojik alan bilgilerini belirlemede ve durumlarını tam olarak yansitmada yetersiz kalabilir. $\mathrm{Bu}$ nedenle mevcut çalışmanın bizzat öğretmenlik mesleğinin içinde olan ve öğretim sürecinde rol oynayan öğretmenlerle yapılmasına karar verilmiştir. Buradan hareketle yapılan bu araştırmanın amacını lise matematik ögretmenlerinin türevin tanımına, türevin tanımının görselleştirilmesine ve türev-süreklilik ilişkisine yönelik pedagojik alan bilgilerini konu alanı bilgisi bağlamında incelemek teşkil etmiştir.

\section{Yöntem}

\section{Araştırmanın Modeli}

$\mathrm{Bu}$ çalışmada nitel araştırma modellerinden durum çalışması deseni kullanılmıştır. Nitel çalışmalar, araştırma yapılan bireylere yönelik görüşlerin ve konuya yönelik özelliklerinin detaylı şekilde betimlendiği çalışmalardır (Ekiz, 2009). Durum çalışmaları ise sinırları belirli bir kitleye, bir olaya ya da duruma odaklanma firsatı veren ve araştırılan konu üzerinde derinlemesine inceleme yapmayı sağlayan araştırmalardır (Çepni, 2012; Yin, 1994). Mevcut araştırmada lise matematik öğretmenlerinin konu alanı bilgileri arasındaki benzerlikler ve farklılıklar belirleneceğinden durum çalışması tercih edilmiştir.

\section{Araştırmanın Katılımcıları}

2015-2016 öğretim y1lı güz döneminde gerçekleştirilen bu araştırmanın katılımcılarını Karadeniz Bölgesi'nin bir ilinde Milli Eğitim Bakanlığı'na bağlı genel liselerde görev yapan dört matematik öğretmeni oluşturmuştur. Ögretmenler belirlenirken amaçlı örnekleme yöntemlerinden maksimum çeşitlilik örneklemesi kullanılmıştır. Araştırmacılar uygulama yapılmadan önce çalışmanın dört lise 
matematik öğretmeniyle gerçekleştirileceği konusunda görüş birliğine varmıştır. Aynı zamanda çalışmaya katılacak öğretmenlerden ikisinin eğitim fakültesi mezunu diğer ikisinin ise fen-edebiyat fakültesi mezunu öğretmenler olmasına dikkat edilmiştir. Maksimum çeşitlilik örneklemesinde farklı özelliklere sahip bireylerin ortaya koyduğu görüşler genelleme kaygısı duymadan geniş bir perspektiften değerlendirilmektedir (Patton, 1990).

$\mathrm{Bu}$ araştırmada maksimum çeşitlilik örneklemesinin tercih edilmesinin sebebi ise mezun olunan farklı fakültelere ve farklı öğretim deneyimlerine sahip öğretmenlerin bakış açılarından yararlanarak araştırma probleminin çeşitli boyutlarını gün yüzüne çıkarmaktır. Araştırmada lise matematik öğretmenlerinin tercih edilmesinin sebebi ise araştırmaya katılan öğretmenlerin lisans öğrenimleri sırasında Analiz I-II ile matematik öğretimi derslerini almış olmalarıdır. Araştırmanın ortaöğretim on ikinci sınıf düzeyinde yapılmasının sebebi ise bu düzeydeki matematik ders programında türev konusunun yer almış olmasıdır. Araştırmaya katılan öğretmenlerin kimliklerini gizlemek amaciyla öğretmenlere $\mathrm{O}_{1}, \ddot{\mathrm{O}}_{2}, \ddot{\mathrm{O}}_{3}$ ve $\ddot{O}_{4}$ şeklinde kodlar verilmiştir. Lise matematik öğretmenlerinin demografik özelliklerine yönelik bilgiler tablo 1'de sunulmuştur.

Tablo 1. Öğretmenlerin Demografik Özellikleri

\begin{tabular}{cccc}
\hline$\ddot{O} \breve{g r e t m e n l e r ~}$ & Mezuniyet & Cinsiyet & Hizmet Süresi \\
\hline$\ddot{O}_{1}$ & FEF & Bay & 9 yıl \\
$\ddot{O}_{2}$ & EF & Bayan & 15 yll \\
$\ddot{O}_{3}$ & EF & Bay & 23 y1l \\
$\ddot{O}_{4}$ & FEF & Bayan & 4 yıl \\
\hline
\end{tabular}

EF: Eğitim Fakültesi, FEF: Fen Edebiyat Fakültesi

Öğretmenlerle yapılan ön görüşmeler sonunda sadece $\ddot{O}_{2}$ lisansüstü eğitim gördüğünü açıklamıştır. Ö ${ }_{3}$ ile yapılan ön görüşmelerde, $\mathrm{O}_{3}$ lisans not transkript belgesini birinci araştırmacıya göstermiş ve matematik öğretimi dersini aldığını teyit etmiştir. Ö ${ }_{1}$ ve $\ddot{\mathrm{O}}_{4}$ matematik öğretme bilgilerine yönelik herhangi bir kursa/seminere 
katılmadıklarını belirtmiştir. Ancak öğretmenlerden $\ddot{O}_{2}$ geogebra kullanımına yönelik seminere katılıdğını ifade ederken, $\ddot{O}_{3}$ geometri öğretimine ve müfredat değişikliğine yönelik kurslara katıldığını açıklamıştır. Öğretmenlerden $\ddot{O}_{1}, \ddot{O}_{2}$ ve $\ddot{O}_{3}$ türevin öğretimine yönelik kendilerini "yeterli" bulduklarını belirtirken Ö 4 türev öğretiminde kendisini "yetersiz" bulduğunu ifade etmiştir. Öğretmenlerden Ö̈ ve $\ddot{\mathrm{O}}_{3}$ lisans döneminde matematik dersindeki başarılarını "çok iyi" şeklinde açıklarken $\ddot{O}_{2}$ ve $\ddot{O}_{4}$ lisans döneminde matematik dersindeki başarılarını "orta" şeklinde belirtmiştir.

\section{Veri Toplama Aracı}

Araştırmada lise matematik öğretmenlerinin türevin tanımına, türevin tanımının görselleştirilmesine ve türev-süreklilik ilişkisine yönelik pedagojik alan bilgilerini konu alanı bilgisi bağlamında ortaya çıkarmak amacıyla araştırmacılar tarafından geliştirilmiş olan yarı yapılandırılmış görüşme formu kullanılmıştır. Görüşme formunun geliştirilmesi süresinde türev konusunu inceleyen çalışmalar (Duru, 2006; Yıldız, 2006) ve pedagojik alan bilgisini inceleyen çalışmalar (Alev \& Karal, 2013; Canbazoğlu vd., 2010; Dani, 2004; Işıksal, 2006) dikkate alınmıştır.

Taslak haldeki görüşme formunda üç bölüm ve her bölüm içerisinde bir soru bulunmaktadır. Görüşme formunun bölümleri sırasıyla "türevin tanımını açıklama", "türevin tanımını görselleştirme" ve "türev-süreklilik ilişkisi" şeklinde isimlendirilmiştir. Nihai görüşmeler öncesi araştırmanın kapsam geçerliğini arttırmak amacıyla formdaki sorular, türev alanında çalışma yapan iki öğretim üyesi, matematik eğitimi alanında çalışma yapan iki araştırma görevlisi ve bir matematik öğretmeni olmak üzere beş uzman tarafından incelenmiştir.

Uzmanların görüşleri alınarak soru köklerinde bazı düzeltmelere gidilmiştir. Buna göre taslak görüşme formunda "Türev kavramı hakkında bilgi verebilir misiniz? Size göre türev ne demektir?" şeklinde yer alan birinci soru için kavramların kişiden kişiye değişiklik göstermemesi ve ikinci soru parçasının ilk soru parçasından daha farklı cevaplara ulaştırmaması gerekçesiyle formun birinci sorusunun "Türev kavramı hakkında bilgi verebilir misiniz?" şeklinde 
kalmasına karar verilmiştir. "Verdiğiniz bilgiler doğrultusunda türev kavramıyla ilgili zihninizde canlanan şekli çizer misiniz?" şeklindeki ikinci soruda uzmanlar, yapılan çizimlerde sınırlama olmaması için ögretmenlerin zihinde canlanan objenin şekil olmasının yanı sıra grafik ya da tablo gibi görselleri kullanarak verecekleri cevapların da dikkate alınması gerektiğini belirtmiştir. $\mathrm{Bu}$ nedenle formun ikinci sorusu "...zihninizde canlanan şekli/grafiği/tabloyu çizer misiniz?" şeklinde düzeltilmiştir. "Türev kavramı ile süreklilik kavramı arasında herhangi bir ilişki var mıdır?Varsa cebirsel/görsel olarak nasıl açıklarsınız?" şeklindeki üçüncü ve son soruda uzmanlar, öğretmenlerin bu iki kavram arasında ilişki olmadığını ve bu durumun nedenini kendilerince açıklayabileceklerinin göz önünde bulundurulması gerektiğini belirtmiştir. $\mathrm{Bu}$ nedenle görüşme formunun üçüncü sorusuna “...yoksa neden yoktur?" şeklinde soru parçasının eklenmesine karar verilmiştir.

Taslak haldeki görüşme formunun pilot uygulaması 2015-2016 öğretim y1lı güz döneminde iki lise matematik öğretmeniyle ders saatleri dişındaki boş saatlerde gerçekleştirilmiştir. Pilot uygulamalar her iki öğretmen için 30 dakika sürmüştür. Pilot uygulama sonunda öğretmenlerin güçlük çektikleri sorular iki öğretim üyesi, bir araştırma görevlisi ve dil bilgisi alanında uzmanlaşmış bir türkçe öğretmeni tarafindan tekrar incelenip yeniden düzenlenmiștir. Son hali verilen görüşme formunun nihai uygulaması yapılmadan önce ilgili kurumlardan resmi izinler alınmıştır. Aynı zamanda görüşmenin yapılacağı öğretmenin bağlı bulunduğu okul idaresi de yapılacak olan bu görüşmelerden haberdar edilmiştir. Nihai uygulama öncesi görüşme yapılacak öğretmenlere; görüşmelerin gönüllülük esasına bağlı gerçekleştirileceği, yapılan uygulamanın sadece bilimsel bir çalışmada kullanılacağı ve kimliklerin gizli tutulacağı açıklanmıştır. Ancak buna rağmen nihai uygulama için belirlenen altı lise matematik öğretmeninden bir bay ve bir bayan öğretmen çok yoğun oldukları gerekçesiyle görüşmelere katılamayacaklarını bildirmiştir. Geriye kalan dört öğretmen nihai uygulamaya kendi istekleri doğrultusunda katılmak istediklerini belirtmiştir.

Nihai uygulama 2015-2016 öğretim yıl1 güz döneminde öğretmenlerin görev yaptıkları okulların kantinlerinde ve dersin olmadığı boş vakitlerde gerçekleştirilmiştir. Öğretmenlerin her biriyle 
yapılan görüşmeler 25 dakika sürmüştür. Görüşme formundaki sorular ögretmenlerin her birine aynı sırayla sorulmuştur. Görüşmelerin tamamı ses kayıt cihazıyla kaydedilmiştir. Çizim gerektiren yerlerde kamera yardımıyla video kaydı yapılmıştır. Görüşmeler sonrası elde edilen kayıtlar araştırmacılardan biri tarafından transkript edilmiştir. Transkriptler sonunda her bir öğretmenle yapılan görüşmeler ses kayıt cihazından ve kameradan tekrar takip edilmiştir. Böylece transkriptlerin doğru oluşturulup oluşturulmadığg teyit edilmiştir.

\section{Verilerin Analizi}

Araştırmanın verileri içerik analizi tekniğiyle incelenmiştir. İçerik analizinde veri toplama araçlarından elde edilen veriler benzer ve farklı özelliklerine göre sistematik şekilde tasnif edilerek kategoriler ve kodlar çerçevesinde bütünleştirilip okuyucunun anlayacağ1 şekilde düzenlenir (Tavşancıl \& Aslan, 2001; Yıldırım \& Şimşek, 2013). Bu araştırmada türevin tanımından, türevin tanımının görselleştirilmesinden ve türev-süreklilik ilişkisinden elde edilen verilerin kategoriler ve kodlar altında tanımlanması sürecinde Zazkis ve Leiken (2008) tarafından belirlenen ve Gökkurt (2014) tarafından genişletilen çerçeve kullanılmıştır. $\mathrm{Bu}$ çerçevede erişebilirlik, doğruluk, zenginlik ve genelleştirme olmak üzere dört kategori bulunmaktadir.

Erişebilirlik kategorisinde; zorlanmadan kisa süre içinde verilen cevaplar kolay verilmiş cevap, duraksayarak verilen cevaplar zor verilmiş cevap, sorulara zorlanarak cevap verirken kısa bir süre düşünüp sonra verilen cevaplar kismen zor verilmiş cevap, herhangi bir şekilde verilmeyen cevaplar ise cevap yok kodu altında tanımlanmıştır.

Doğruluk kategorisinde; kavrama yönelik kritik özelliklerin tümünü içinde barındıran açıklamalar gerekli ve yeterli, kritik özelliklerinin bir bölümünün olduğu açıklamalar gerekli ve yetersiz, kritik olan ve olmayan özellikler içeren ancak kritik özelliklerin tümünü barındırmayan açıklamalar klsmen gerekli ve yetersiz, hiçbir kritik özellik içermeyen açılamalar ise ne gerekli ne yeterli kodu altında tanımlanmıştır.

Zenginlik kategorisinde; ders kitaplarında ve alan öğretim kitaplarında yer alan günlük hayat örnekleri ile çizimler prototip 
örnek, ders ve alan kitaplarında yer almayan günlük hayat örnekleri ile çizimler ise prototip olmayan örnek kodu altında tanımlanmıştır. Günlük hayattan verilen örnekler öğrencilerin zihinlerinde doğru kavram imaj1 oluşturmaya olanak veriyorsa uygun örnek, örnekler öğrencilerin zihinlerinde oluşan kavram imajıyla tam olarak örtüşmüyorsa klsmen uygun örnek kodu altında değerlendirilmiştir.

Genelleştirme kategorisinde; kavrama yönelik yapılan tanım başka kavramların tanımlarını içermiyorsa özel tanım, başka kavramların tanımlarını da içeriyorsa genel tanım kodu altında değerlendirilmiştir. $\mathrm{Bu}$ araştırmada öğretmenlerin görüşme formundaki sorulara verdikleri cevaplar ayrı ayrı her bir araştırmacı tarafindan benzerliklerine ve farklılıklarına göre tasnif edilmiştir. Daha sonra iki araştırmacının oluşturduğu kodlar, karşılaştırma yapmak suretiyle bir araya getirilerek görüş birliğine varılıp tekrar düzenlenmiştir. Çalışmayla ilgisi olmadığı düşünülen ve bir anlam verilemeyen kodlar araştırma dişında tutulmuştur. Araştırmacılar arasındaki kodlamalara yönelik uyum yüzdesi Miles ve Huberman (1994)'ün güvenirliği hesaplama formülüne göre .87 bulunmuştur.

Araştırmanın kalitesini yükseltmek için çalışma sürecinde bazı stratejiler (Yıldırım, 2010) uygulanmıştır. Buna göre öğretmenlerden elde edilen veriler üzerinde daha fazla düşünerek araştırmanın daha tutarlı olmasını sağlamak ve daha farklı bakış açısın geliştirmek amaciyla (Glesne \& Peshkin, 1992; akt. Roberts \& Priest, 2006) araştırma sonunda bütün öğretmenlerle bire bir görüşmeler yapılmıştır. $\mathrm{Bu}$ görüşmelerde nihai uygulamada beğenilen bölümler, dikkat çeken yönler ve karşılaşılan zorluklara yönelik öğretmen dönütleri alınmıştır. Geçerliği arttırmak amacıyla çeşitleme yoluna gidilerek (Glesne, 2013) görüşme ve doküman analizi gibi birden fazla veri toplama aracı kullanılmıştır.

Uygulamaya katılan öğretmenlerin araştırmacıya olan güvenini arttırmak ve olguların daha kolay ortaya çıkarmak amacıyla (Daymon \& Holloway, 2003) her bir öğretmenle yirmi beş dakikalık görüşmeler gerçekleştirilmiştir. Okuyucuların gözünde şeffaf bir araştırma algısı yaratmak amacıyla (Twycross \& Shields, 2005) araştırmanın yöntemi ile bulgular açık ve net bir şekilde yansıtılmıştır. Araştırmacılar dışında farklı bir uzman tarafından değerlendirilen araştırmaların niteliğinin artacağı düşüncesiyle (Marvasti, 2004) araştırmacılar 
tarafindan oluşturulan kodlar nitel araştırma alanında uzmanlaşmış bir öğretim üyesine gösterilmiş ve yapılan kodlamalara yönelik teyit alınmıştır.

\section{Bulgular}

\section{Türevi Tanımlama ve Örneklendirme}

Tablo 2'de öğretmenlerin türevle ilgili yaptıkları tanımların ve örneklerinin Zazkis ve Leiken (2008)'in kategorilerine göre değerlendirmesi yapılmıştır.

Tablo 2.Türevin Tanımına ve Örneklerine Yönelik Kategoriler/Kodlar

\begin{tabular}{|c|c|c|}
\hline Kategoriler & Kodlar & Öğretmen kodları \\
\hline \multirow[t]{4}{*}{ Erişebilirlik } & Kolay verilmiş cevap & $\ddot{\mathrm{O}}_{2} \ddot{\mathrm{O}}_{3}$ \\
\hline & Kısmen zor verilmiş cevap & $\ddot{\mathrm{O}}_{4}$ \\
\hline & Zor verilmiş cevap & $\ddot{O}_{1}$ \\
\hline & Cevap yok & \\
\hline \multirow[t]{4}{*}{ Doğruluk } & Gerekli ve yeterli & \\
\hline & Gerekli ve yetersiz & $\ddot{\mathrm{O}}_{1} \ddot{\mathrm{O}}_{2} \ddot{\mathrm{O}}_{3} \ddot{\mathrm{O}}_{4}$ \\
\hline & Kismen gerekli ve yetersiz & \\
\hline & Ne gerekli ne yeterli & \\
\hline \multirow[t]{2}{*}{ Zenginlik } & Prototip örnek verme & $\ddot{\mathrm{O}}_{1} \ddot{\mathrm{O}}_{2} \ddot{\mathrm{O}}_{4}$ \\
\hline & Prototip olmayan örnek verme & $\ddot{\mathrm{O}}_{3}$ \\
\hline \multirow[t]{2}{*}{ Genelleştirme } & Özel tanım kullanma & $\ddot{\mathrm{O}}_{1} \ddot{\mathrm{O}}_{3} \ddot{\mathrm{O}}_{4}$ \\
\hline & Genel tanım kullanma & $\ddot{\mathrm{O}}_{2}$ \\
\hline
\end{tabular}

Tablo 2'de verilen bulgular erişebilirlik açısından incelendiğinde, iki öğretmenin türevin tanımını ve türeve yönelik örnekleri çaba sarf etmeden cevapladıkları görülmüştür. Diğer taraftan yapılan görüşmelerde, Ö$_{1}$ öğretmeninin türevin tanımını yaparken 
biraz düşünerek cevap verdiği ortaya çıkmıştır. Doğruluk açısından ele alındığında ise, öğretmenlerin tamamının türevin tanımında olması gereken kritik özelliklerin bazılarını doğru söyledikleri bazılarını ise söylemedikleri görülmüştür. Buradan hareketle tüm öğretmenlerin türevi doğru ancak eksik tanımladıkları söylenebilir. Öğretmenlerin türevle ilgili yaptıkları tanımlar tablo 3 'te sunulmuştur.

Tablo 3. Öğretmenlerin Türevin Tanımına İlişkin Görüşleri

$\mathrm{f}(\mathrm{x}),[\mathrm{a}, \mathrm{b}]$ aralığında sürekli olsun. $\lim _{x \rightarrow x_{0}} \frac{f(x)-f\left(x_{o}\right)}{x-x_{0}}=f^{\prime}\left(x_{0}\right)$

Yani burada pay kısmındaki yazdığımız y'deki değişim, payda kısmında yazdığımız ise x’teki değişim. y'deki değişimin x’teki değişime oranı, yani o çok küçük mesafedeki oran bize o anlık değişimi verecek. Buna biz $\mathrm{x}_{\mathrm{o}}$ noktasındaki türev diyeceğiz $\left(\ddot{O}_{1}\right)$

Belli bir andaki türevi bulmak istiyorsak bunu limitle ilişkilendiririz. Yani $\lim _{x \rightarrow x_{0}} \frac{f(x)-f\left(x_{o}\right)}{x-x_{0}} \quad$ şeklinde ifade edebiliriz $\left(\ddot{O}_{2}\right)$

$\mathrm{f}(\mathrm{x})$ bir aralıkta sürekli olsun. Yani $\lim _{h \rightarrow 0} \frac{f(x+h)-f(x)}{h}=f^{\prime}\left(x_{0}\right) \quad$ "h"sıfir'a giderken " $\mathrm{f}(\mathrm{x}+\mathrm{h})-\mathrm{f}(\mathrm{x})$ " bölü " $\mathrm{h}$ " limitinin değeri fonksiyonun türevidir $\left(\mathrm{O}_{3}\right)$

Bir eğrinin bir noktadaki eğimi diyebiliriz. Ya da çok yakın değerlerdeki değişim oranı türevi verir. Limitle bağlantılı olduğunu düşünüyorum. Cebirsel olarak bu şekilde ifade $\lim _{x \rightarrow h} \frac{f(x+h)-f(x)}{h}$ edebiliriz türevi $\left(\ddot{O}_{4}\right)$

Tablo 3'teki öğretmen tanımları ayrıntılı incelendiğinde, yapılan tanımların gereksiz bilgi ya da eksik bilgi içerdiği görülmüştür. Balcı (1999), Demir (2014), Thomas, Weir, Hass ve Giordano (2009) ile Kadıoğlu ve Kamalı (2009)'a göre türevin tanımında açılanan "fonksiyonun tanım ve değer kümelerinin belirtilmesi, türevi aranacak noktanın özelliklerinin belirtilmesi ve fonksiyondaki artmanın değişkendeki artmaya oranının, değşkendeki artmanın sıfira yaklaşması halindeki limitini gösteren formülün belirtilmesi" 
durumları dikkate alındığında öğretmenlerin yaptıkları tanımların tam doğru tanımlar olduğu söylenemez. Ö${ }_{1}$ öğretmeninin yaptığ tanımda belirtilen kapalı aralığın hangi kümenin bir alt kümesi olduğu net şekilde ifade edilmemiş ve türevin cebirsel tanımı yoluyla bulunan limit değerinin fonksiyonun $\mathrm{x}=\mathrm{x}_{\mathrm{o}}$ noktasındaki türevine karş11 $\mathrm{k}$ geldiği belirtilmemiştir. $\ddot{O}_{2}, \quad \ddot{O}_{3}$ ve $\ddot{O}_{4}$ öğretmenlerinin yaptıkları tanımlarda ise fonksiyonun tanım ve değer kümeleri ile türevi aranacak $\mathrm{x}_{\mathrm{o}}$ noktasının hangi kümenin bir elemanı olduğu açık ve net bir şekilde belirtilmemiştir. Ayrıca $\ddot{O}_{3}$ ve Ö$_{4}$ öğretmenleri tarafından "h" artım ifadesinin hangi kavrama karşılık yazıldığı ve bu kavrama nasıl ulaşıldığı belirtilmemiştir.

Öte yandan tüm öğretmenler türevin tanımını yaparken bu kavramın günlük hayatta kısaca neyi ifade ettiğini açıklamaya ve örneklendirmeye çalışmıştır. Buna göre öğretmenlerden Ö ${ }_{1}$ türevi "anlık değişim... Ondan sonra değişim hızı diyebiliriz. Bir şeyin en'ini (en büyük değer, en küçük değer, en yüksek hız) bulmak için kullandığımı matematiksel kavram" şeklinde belirtmiştir. Öğretmenlerden $\mathrm{O}_{2}$ türevi "anlık değişimdir. Mesela bir taşı durgun bir suya attığınızda su üzerinde oluşan halkaları düşünelim. Önce küçük bir çember sonra biraz daha büyük bir yarıçapa sahip çember öyle büyüyerek gidiyor. İște biz suyun taşa dokunduğu andan itibaren belli bir saniyedeki, o anlık, çemberin çevresinin büyümesini hesap ettiğimizi düşünelim. Işste burada türev devreye girecektir. Anlık değişim hızını verecektir" şeklinde kısaca açıklamış ve örneklendirmiştir. Öğretmenlerden $\mathrm{O}_{3}$ türevi "azaltılmış, küçültülmüş... Mesela çayın en son kalmış hali" şeklinde ifade etmiştir. Öğretmenlerden Ö$_{4}$ ise türevi bir eğrinin bir noktadaki "değişim oranı" şeklinde açıklamıştır.

Öğretmenlerin verdikleri cevaplar zenginlik kategorisine göre incelendiğinde $\ddot{\mathrm{O}}_{1}, \mathrm{O}_{2}$ ve $\ddot{\mathrm{O}}_{4}$ öğretmenleri tarafından verilen günlük hayat örneklerinin lise matematik ders kitaplarında (Aydın \& Erbaş, 2011; Çakımcı \& Kabasakal, 2016; Çarhoğlu \& Gezmiş, 2015; Gürler \& Yılmaz, 2016) ve alandaki matematik öğretim kitaplarında (Balc1, 1999; Çetinkaya, Erbaş \& Alacalı, 2013; Demir, 2014; Thomas vd., 2009, Yağc1, 2014) yer alması bu örneklerin prototip olma özelliğine sahip olduğunu ortaya koymuştur. Ancak $\ddot{O}_{3}$ ögretmeninin türevle ilgili verdiği örneklerin prototip örnekler olmadığı söylenebilir. Bunun 
dışında $\mathrm{O}_{1}, \ddot{O}_{2}$ ve $\ddot{O}_{3}$ öğretmenlerinin türevle ilgili günlük yaşamdan öne sürdükleri örneklerin uygunlukları incelendiğinde $\ddot{O}_{1}$ ve $\ddot{O}_{2}$ öğretmenleri tarafından öne sürülen "anlık değişim” ile Ö ${ }_{4}$ öğretmeni tarafindan öne sürülen "değişim oranı" örneklerinin türevi çağrıştırdığ 1 ve bireylerin zihinlerine yer edecek doğru bir kavram imaj1 olduğu söylenebilir. $\mathrm{Bu}$ nedenle bu öğretmenler tarafından verilen örnekler "uygun örnek" kategorisinde değerlendirilmiştir. $\mathrm{O}_{3}$ öğretmeni tarafından öne sürülen "azaltılmış, küçültülmüş" şeklindeki örneklerin her zaman türev kavramını yansıttığ1 söylenemeyebilir. Örneğin polinom fonksiyonlarda türev aranırken üs derecesi her bir türev alma işleminde bir küçülmektedir. Ancak bazı negatif rasyonel şeklindeki polinom fonksiyonların türevleri incelendiğinde tek sayılı türevlerde pozitif sonuçlar çıkarken çift sayılı türevlerde ise negatif sonuçlar çıkmaktadır. Bu durumda ortaya çıkan sonuçlar türevin devamlı azalmaya ya da küçülmeye gitmesi durumuyla örtüşmemektedir. Bu nedenle $\mathrm{O}_{3}$ öğretmeni tarafından öne sürülen bu örnek "klsmen uygun örnek" kategorisinde değerlendirilmiştir.

Öğretmenlerin verdikleri cevaplar genelleştirme kategorisine göre incelendiğinde $\ddot{\mathrm{O}}_{1}, \ddot{\mathrm{O}}_{3}$ ve $\ddot{\mathrm{O}}_{4}$ öğretmenlerinin ileri sürdükleri tanımların sadece türevle ilgili kritik özellikleri ortaya koyan tanımlar olduğu ifade edilebilir. Bu nedenle $\ddot{O}_{1}, \ddot{O}_{3}$ ve $\ddot{O}_{4}$ tarafından ileri sürülen tanımlar "özel tanım" kategorisinde değerlendirilmiştir. Ancak $\mathrm{O}_{2}$ öğretmeninin ileri sürdüğ̈̈ tanımın sadece türevin kritik özelliklerini ortaya koyan bir tanım olmadığı görülmektedir. Nitekim

burada öğrenci, tanım olarak verilen

$$
\lim _{x \rightarrow x_{0}} \frac{f(x)-f\left(x_{o}\right)}{x-x_{0}}
$$

ifadesini limit konusuyla ilgili bir kavram olarak da düşünebilir. $\mathrm{Bu}$ nedenle $\mathrm{O}_{2}$ öğretmeni tarafindan ileri sürülen tanım sadece türevle ilgili olmayıp limitle de ilişkili olduğundan "özele yakın tanım" kategorisinde değerlendirilmiştir.

\section{Türevin Tanımını Görselleştirme}

Tablo 4'te öğretmenlerin türev tanımının görselleştirilmesine yönelik etkinlikleri Zazkis ve Leiken (2008)'in kategorilerine göre değerlendirilmiştir. Öğretmenlerin türevin tanımına yönelik sadece çizim örnekleri incelendiğinden ve tanım yapılması istenmediğinden genelleştirme kategorisi dikkate alınmamıştır. 
M. Duran, A. Kaplan / Ë̈ Eğitim Fakültesi Dergisi, 18-2 (2016), 795-831

Tablo 4.Türevin Tanımını Görselleştirmeye Yönelik Kategoriler/Kodlar

\begin{tabular}{|c|c|c|}
\hline Kategoriler & Kodlar & Öğretmen kodları \\
\hline \multirow[t]{4}{*}{ Erişebilirlik } & Kolay verilmiş cevap & $\ddot{\mathrm{O}}_{1} \ddot{\mathrm{O}}_{2} \ddot{\mathrm{O}}_{3} \ddot{\mathrm{O}}_{4}$ \\
\hline & Kısmen zor verilmiş cevap & \\
\hline & Zor verilmiş cevap & \\
\hline & Cevap yok & \\
\hline \multirow[t]{4}{*}{ Doğruluk } & Gerekli ve yeterli & $\ddot{\mathrm{O}}_{1}$ \\
\hline & Gerekli ve yetersiz & $\ddot{\mathrm{O}}_{2} \ddot{\mathrm{O}}_{3} \ddot{\mathrm{O}}_{4}$ \\
\hline & Kismen gerekli ve yetersiz & \\
\hline & Ne gerekli ne yeterli & \\
\hline \multirow[t]{2}{*}{ Zenginlik } & Prototip örnek verme & $\ddot{\mathrm{O}}_{1} \ddot{\mathrm{O}}_{2} \ddot{\mathrm{O}}_{3} \ddot{\mathrm{O}}_{4}$ \\
\hline & Prototip olmayan örnek verme & \\
\hline
\end{tabular}

Tablo 4'te verilen bulgular erişebilirlik açısından incelendiğinde, $\ddot{\mathrm{O}}_{1}, \ddot{\mathrm{O}}_{2}, \ddot{\mathrm{O}}_{3}$ ve $\ddot{\mathrm{O}}_{4}$ 'ün türevin tanımına yönelik görselleri çaba sarf etmeden çizdikleri görülmektedir. Bu doğrultuda, öğretmenlerin verdikleri cevaplar erişebilirlik açısından kolay verilen cevap olarak değerlendirilmiştir. Doğruluk açısından incelendiğinde ise $\ddot{O}_{1}$ öğretmeninin yapmış oldukları çizimlerin türevin tanımı için bütün kritik özellikleri barındırdı $\breve{g}_{1}, \ddot{\mathrm{O}}_{2}, \ddot{\mathrm{O}}_{3}$ ve $\ddot{\mathrm{O}}_{4}$ öğretmenlerinin yaptıkları çizimlerin ise türevin tanımı için gerekli ancak yetersiz özellikte olduğu görülmüştür. Öğretmenlerin türevin tanımına yönelik çizim örnekleri şekil 1'de sunulmuştur. 

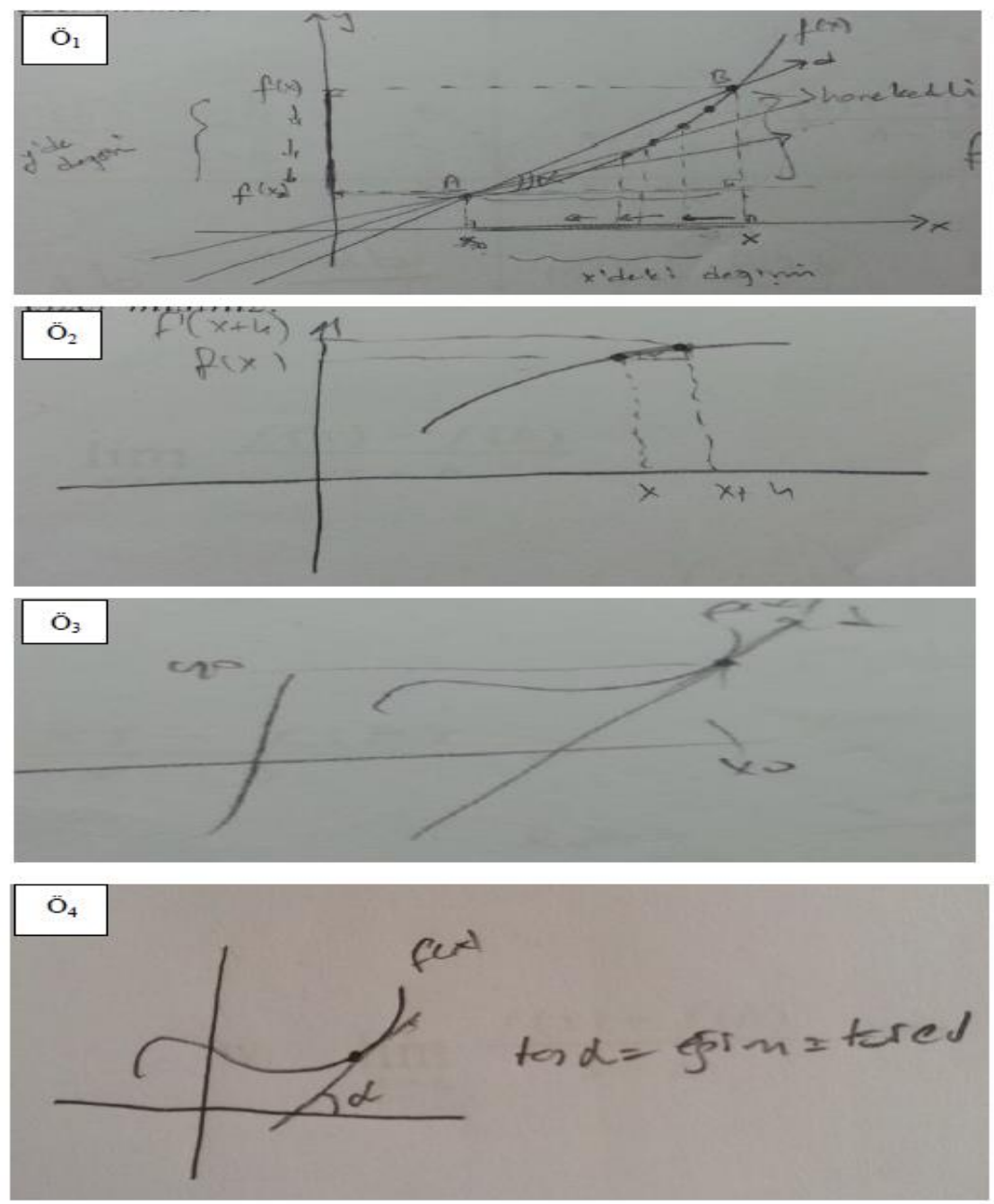

Şekil 1.Öğretmenlerin Türevin Tanımına Yönelik Çizim Örnekleri

Şekil 1 incelendiğinde öğretmenlerin lise ders kitaplarında (Çakımcı \& Kabasakal, 2016; Çarhoğlu \& Gezmiş, 2015) ve alandaki matematik öğretim kitaplarında (Balc1, 1999; Kadığlu \& Kamalı, 2005; Thomas vd., 2009; Yağc1, 2014) yer alan türev-değişim oranı, türev-eğim ilişkilerine yönelik örnekler çizdikleri görülmüştür. Bununla birlikte öğretmenler türev tanımına yönelik ders kitapları ve 
alan öğretim kitaplarında olmayan farklı çizimlere yer vermemiştir. $\mathrm{Bu}$ kapsamda öğretmenlerin yapmış oldukları çizimler zengin örnek olarak değerlendirilmemiştir. Öğretmenlerin türevin tanımına yönelik çizim örneklerini ayrıntılı incelemek amacıyla, Aydın ve Erbaş (2011), Balcı (1999), Çarhoğlu ve Gezmiş (2015), Çetinkaya ve diğerleri (2013), Demir (2014), Thomas ve diğerleri (2009) ile Yağc1 (2014)'ün çalışmalarındaki türev tanımının görselleştirilmesini yansıtan kritik özellikler dikkate alınmıştır. Bu kritik özellikler; belirli bir aralıkta tanımlı olan bir fonksiyon eğrisinin çizilmesi, eğri üzerinde biri sabit diğeri hareketli iki noktanın belirlenmesi, hareketli noktanın yavaşça sabit noktaya doğru kaydırılması, eğri üzerindeki kirişin fonksiyon eğrisine teğet olduğunun belirtilmesi, türev-eğim ilişkisinin cebirsel tanımlanması ve türev-eğim arasındaki ilişskinin belirtilmesi şeklinde açıklanmıştır. Buna göre öğretmenlerin türevin tanımının çizimine yönelik hangi özellikleri dikkate aldıkları tablo 5 'te araştırmacılar tarafından oluşturulan kategorilere ve kodlara göre incelenmiştir.

Tablo 5.Türevin Tanımının Çizimine Yönelik Kategori Ve Kodlar

\begin{tabular}{|c|c|c|c|c|c|}
\hline \multirow[b]{2}{*}{ 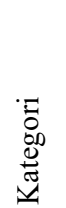 } & \multirow[b]{2}{*}{ Kodlar } & \multicolumn{3}{|c|}{ Ölçütler } & \multirow[b]{2}{*}{ Destekleyici Cümleler } \\
\hline & & Evet & Kismen & Hayır & \\
\hline
\end{tabular}

\begin{tabular}{|c|c|c|c|c|c|}
\hline & $\begin{array}{l}\text { Belirli bir aralıkta } \\
\text { tanımlı bir fonksiyon } \\
\text { eğrisinin çizilmesi }\end{array}$ & $\ddot{\mathrm{O}}_{1} \mathrm{O}_{3}$ & $\ddot{\mathrm{O}}_{2} \ddot{\mathrm{O}}_{4}$ & & $\begin{array}{l}\text { Söyle bir } f(x) \text { ĕgrisi alalım. Bu herhangi } \\
\text { bir eğri olabilir. Bir }(a, b) \text { aralı̆ğnda } \\
\text { tanımlı olsun }\left(\ddot{O}_{4}\right)\end{array}$ \\
\hline 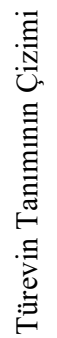 & $\begin{array}{l}\text { Eğri üzerinde } \\
\text { biri sabit diğeri } \\
\text { hareketli iki } \\
\text { noktanın } \\
\text { belirlenrnesi }\end{array}$ & $\ddot{\mathrm{O}}_{1} \ddot{\mathrm{O}}_{2}$ & $\mathrm{O}_{3}$ & $\ddot{\mathrm{O}}_{4}$ & $\begin{array}{l}\text { Bu eğri üzerinde x'imiz bu nokta olsun. } \\
\text { Bu noktanın görüntüsüne de } f(x) \\
\text { diyelim. Şimdi } \quad \text { x'ten } h \text { kadar } \\
\text { uzaklaşlyoruz. } \quad \text { Sağa } \\
\text { Uzaklaştığımız bu nokta }(x+h) \text { iken } \\
\text { görüntüsü de } f(x+h) \text { olacaktır. Bu } \\
\text { noktayı hareketli kabul edelim }\left(\ddot{O}_{2}\right)\end{array}$ \\
\hline
\end{tabular}


M. Duran, A. Kaplan / Ë̈ Ĕ̈itim Fakültesi Dergisi, $18-2$ (2016), 795-831

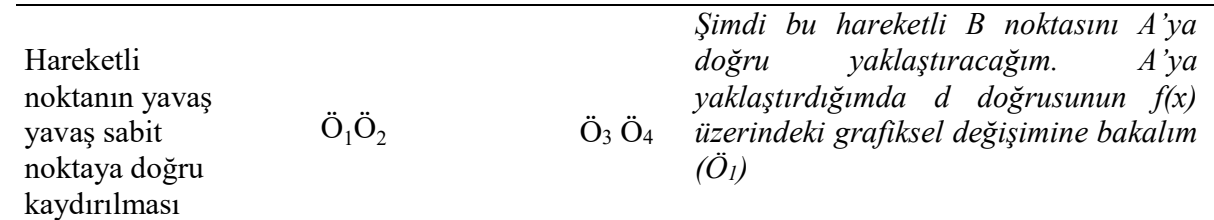

\begin{tabular}{|c|c|c|c|}
\hline $\begin{array}{l}\text { Eğri üzerindeki } \\
\text { kirişin eğriye teğet } \\
\text { olduğunun } \\
\text { açılklanması }\end{array}$ & $\ddot{\mathrm{O}}_{1} \ddot{\mathrm{O}}_{2}$ & $\ddot{\mathrm{O}}_{3} \mathrm{O}_{4}$ & $\begin{array}{l}\text { Burada } x \quad \text { noktasındaki teğete } \\
\text { baklyoruz. Teğetin eğimine baklyoruz. } \\
\text { Kaleme dokundukça yani x'e doğru } \\
\text { yaklaştıkça Teğetlerin eğimleri } \\
\text { değişiyor. Bir yerde kiriş teğet oluyor } \\
\left(\ddot{O}_{2}\right)\end{array}$ \\
\hline $\begin{array}{l}\text { Türev-Ĕ̆im } \\
\text { ilişkisinin cebirsel } \\
\text { tanımlanması }\end{array}$ & & & 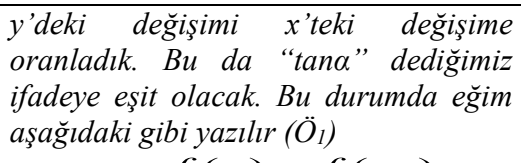 \\
\hline
\end{tabular}

$\ddot{\mathrm{O}}_{1} \ddot{\mathrm{O}}_{2}$

$\ddot{\mathrm{O}}_{3} \ddot{\mathrm{O}}_{4}$

$\lim _{x \rightarrow x_{0}} \frac{f(x)-f\left(x_{o}\right)}{x-x_{0}}$

\begin{tabular}{|c|c|c|}
\hline $\begin{array}{l}\text { Türev-Eğim } \\
\text { arasindaki } \\
\text { ilişkinin } \\
\text { belirtilmesi }\end{array}$ & $\begin{array}{c}\ddot{\mathrm{O}}_{1} \ddot{\mathrm{O}}_{3} \quad \ddot{\mathrm{O}}_{2} \\
\ddot{\mathrm{O}}_{4}\end{array}$ & $\begin{array}{l}f(x) \text { 'in türevinde } x_{0} \text { 'ın değeri } d \\
\text { doğrusunun eğimini verir }\left(O_{3}\right)\end{array}$ \\
\hline
\end{tabular}

Tablo 5 incelendiğinde Ö$_{1}$ öğretmeninin türevin tanımına yönelik doğru bir çizim yaptığı söylenebilir. Ancak $\mathrm{Ö}_{2}, \ddot{O ̈}_{3}$ ve Ö${ }_{4}^{\prime}$ ün türevin tanımına yönelik yaptıkları çizimlerde bazı kritik özelliklerin dikkate alınmadığ $\breve{1}_{1}$ tespit edilmiştir. Bununla ilgili olarak Ö${ }_{2}$ 'nin yaptığı açıklamalar ile çizimi incelendiğinde $\mathrm{O}_{2}$ 'nin belirli bir aralıkta tanımlı olan bir fonksiyon eğrisinin çiziminde ve türev-eğim arasındaki ilişkiyi ifade etmede yetersiz kaldığı görülmüştür. Ö ${ }_{3}^{\prime} u ̈ n$ yaptığı açıklamalar ile çizimi incelendiğinde $\mathrm{Ö}_{3}$ 'ün eğri üzerinde biri sabit diğeri hareketli iki noktayı belirlemede yetersiz kaldığ söylenebilir. Aynı zamanda $\mathrm{O}_{3}$ hareketli noktayı yavaşça sabit noktaya kaydırma, eğri üzerindeki kirişin eğriye teğet olduğunu açıklama ve türev-eğim ilişkisini cebirsel olarak tanımlama gibi etkinlikleri de gerçekleştirmemiştir. Ö' ${ }_{4}^{\prime}$ ün yaptığ 1 açıklamalar ile çizimi incelendiğinde ise Ö$_{4}$ 'ün belirli bir aralıkta tanımlı olan bir eğrinin çiziminde yeterli olmadığı ifade edilebilir. Ayrıca $\ddot{O}_{4}$ hareketli noktayı 
yavaşça sabit noktaya kaydırma, eğri üzerindeki kirişin eğriye teğet olduğunu açıklama ve türev-eğim ilişkisini cebirsel olarak tanımlama gibi etkinlikleri de gerçekleştirmemiştir.

\section{Türev-Süreklilik İlişkisi}

Tablo 6'da öğretmenlerin türev-süreklilik ilişkisine yönelik etkinlikleri Zazkis ve Leiken (2008)'in kategorilerine göre değerlendirilmiştir. Türev-süreklilik arasındaki ilişki incelendiğinden ve tanım yapılması istenmediğinden genelleştirme kategorisi dikkate alınmamıştır.

Tablo 6.Türev-Süreklilik Ilişkisine Yönelik Kategoriler/Kodlar

\begin{tabular}{|c|c|c|}
\hline Kategoriler & Kodlar & Öğretmen kodları \\
\hline \multirow[t]{4}{*}{ Erişebilirlik } & Kolay verilmiş cevap & $\ddot{\mathrm{O}}_{1} \ddot{\mathrm{O}}_{2} \ddot{\mathrm{O}}_{3}$ \\
\hline & Kısmen zor verilmiş cevap & $\ddot{\mathrm{O}}_{4}$ \\
\hline & Zor verilmiş cevap & \\
\hline & Cevap yok & \\
\hline \multirow[t]{4}{*}{ Doğruluk } & Gerekli ve yeterli & $\ddot{\mathrm{O}}_{1} \ddot{\mathrm{O}}_{2}$ \\
\hline & Gerekli ve yetersiz & $\ddot{\mathrm{O}}_{3} \ddot{\mathrm{O}}_{4}$ \\
\hline & Kismen gerekli ve yetersiz & \\
\hline & Ne gerekli ne yeterli & \\
\hline \multirow[t]{2}{*}{ Zenginlik } & Prototip örnek verme & $\ddot{\mathrm{O}}_{1} \ddot{\mathrm{O}}_{3} \ddot{\mathrm{O}}_{4}$ \\
\hline & Prototip olmayan örnek verme & $\ddot{\mathrm{O}}_{2}$ \\
\hline
\end{tabular}

Tablo 6'da verilen bulgular erişebilirlik açısından incelendiğinde, $\ddot{\mathrm{O}}_{1}, \ddot{\mathrm{O}}_{2}$ ve $\ddot{\mathrm{O}}_{3}$ öğretmenlerinin türev-süreklilik ilişkisini zorlanmadan açıkladıkları ve bu iki kavram arasındaki ilişkiyi gösteren grafikleri kolayca kağıda yansıttıkları görülmüştür. $\mathrm{Bu}$ nedenle bu üç öğretmenin verdikleri cevaplar erişebilirlik açısından kolay verilen cevaplar olarak değerlendirilmiştir. Ancak Ö${ }_{4}^{\prime}$ ün türevsüreklilik ilişkisini grafik yardımıyla belirtirken bir ara duraksadığı ve düşündüğü sonra ise grafiği çizmeye devam ettiği tespit edilmiştir. $\mathrm{Bu}$ nedenle bu öğretmenin verdiği cevap erişebilirlik açısından kısmen 
zor verilmiş cevap kategorisi altında değerlendirilmiştir. Öğretmenlerin yaptıkları açıklamalar doğruluk açısından incelendiğinde $\ddot{O}_{1}$ ve $\ddot{O}_{2}$ taraflarından yapılan açıklamaların ve verilen örneklerin türev-süreklilik ilişkisini yansıttığı, Ö${ }_{3}$ ve Ö 4 öğretmenleri taraflarından yapılan açıklamaların ise gerekli olduğu halde verilen örneklerin yetersiz olduğu görülmüştür. Öğretmenlerin türevsüreklilik ilişkisine yönelik çizim örnekleri şekil 2'de sunulmuştur.
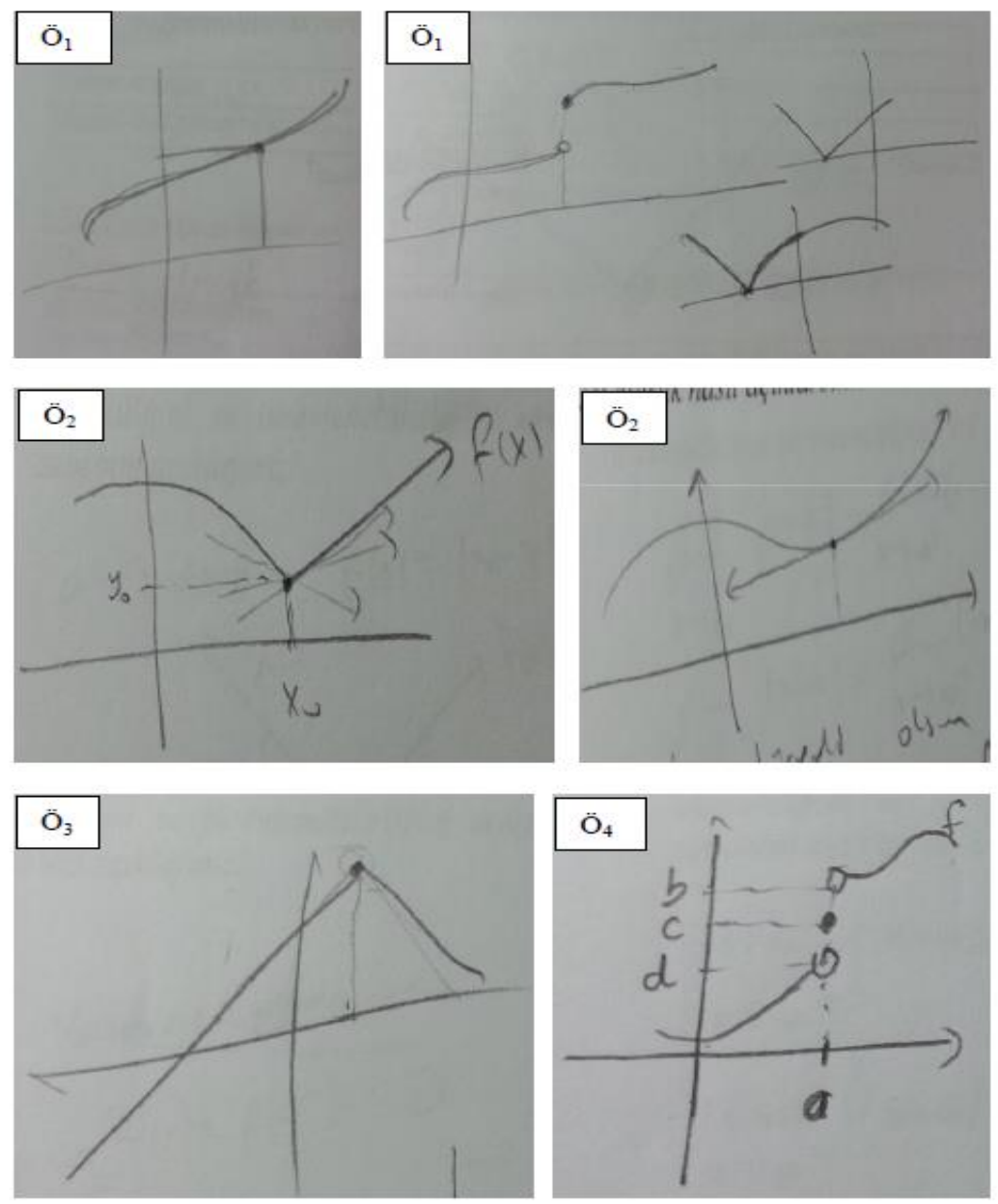

Şekil 2.Türev-Süreklilik Ilişkisine Yönelik Çizim Örnekleri 
Şekil 2 incelendiğinde tüm öğretmenlerin lise ders kitaplarında (Aydın \& Erbaş, 2011; Çakımcı \& Kabasakal, 2016; Çarhoğlu \& Gezmiş, 2015) ve alandaki matematik öğretim kitaplarında (Balc1, 1999; Çetinkaya vd., 2013; Demir, 2014; Thomas vd., 2009, Yağc1, 2014) yer alan türev-süreklilik ilişkisine yönelik örnekler çizdikleri görülmüştür. Bununla birlikte $\ddot{\mathrm{O}}_{2}$ tarafindan belirtilen prototip olmayan örnekler şekil 3 'te sunulmuştur.
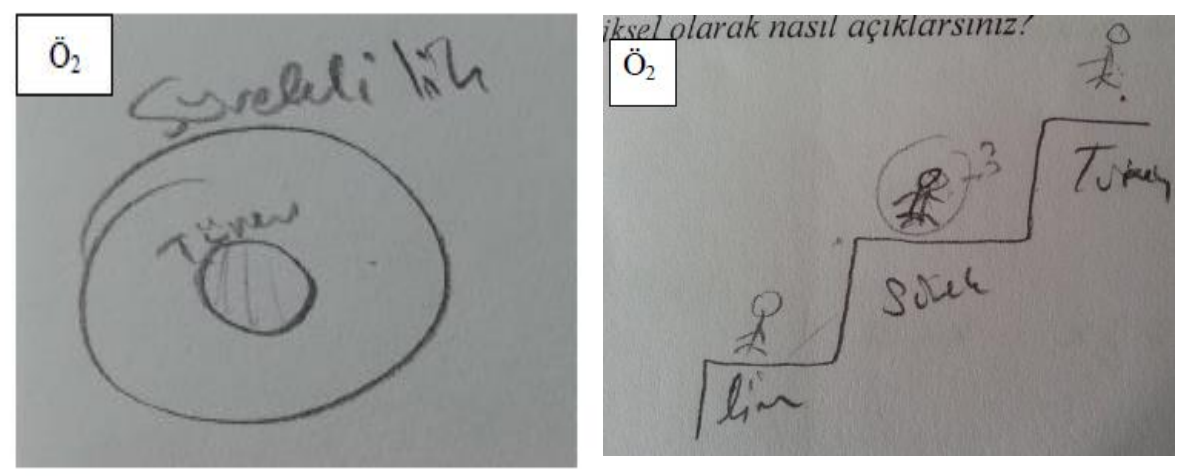

Şekil 3.Türev-Süreklilik Ilişkisine Yönelik Prototip Olmayan Çizim Örnekleri

Şekil 3'te sol tarafta yapılan çizimde $\mathrm{O}_{2}$ türev-süreklilik arasındaki ilişkiyi kümeler konusundaki alt küme kavramından yararlanarak göstermiştir. Şekil 3 'te sağ tarafta yapılan çizimde ise $\mathrm{Ö}_{2}$ türev-süreklilik arasındaki ilişkiye yönelik bir üst basamağa geçildiğinde alt basamaktaki kavramla ilgili özelliklerin de sağlandiğ 1 ifade edilmiştir. Ancak bu örneğin türev-süreklilik ilişkisini yansıtan tam doğru bir çizim örneği olmadığı söylenebilir.

$\ddot{O}_{2}$ 'nin türev-süreklilik ilişkisine yönelik yaptığı bu çizimlerin türev konusunda herkes tarafindan bilindik gösterimler olmadığı ve ders kitapları ile alan öğretim kitaplarında yer almadığı söylenebilir. $\mathrm{Bu}$ nedenle $\ddot{\mathrm{O}}_{2}$ 'nin yaptığı bu çizimler zengin örnek olarak değerlendirilmiştir.

Öğretmenlerin türev-süreklilik ilişkisine yönelik çizim örneklerini daha ayrıntılı incelemek amacıyla Balcı (1999), Çakımcı ve Kabasakal (2016) ile Yağcı (2014)'ün çalışmalarındaki türevsüreklilik ilişkisini yansıtan kritik özellikler dikkate alınmıştır. Bu kritik özellikler; fonksiyonun sürekli olduğu noktada türevli olması, fonksiyonun sürekli olduğu noktada türevli olmaması, fonksiyonun 
sürekli olmadığı bir noktada türevli olmaması ve fonksiyonun türevli olduğu bir noktada sürekli olması şeklinde açıklanmıştır. Buna göre öğretmenlerin türev-süreklilik ilişkisini açıklarken hangi özellikleri dikkate aldıkları tablo 7'de araştırmacılar tarafindan oluşturulan kategorilere ve kodlara göre incelenmiştir.

Tablo 7.Türev-Süreklilik Ilişkisinin Gösterimine Yönelik Kategori Ve Kodlar

\begin{tabular}{|c|c|c|c|c|}
\hline \multirow[b]{2}{*}{ 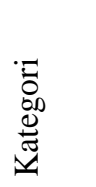 } & \multirow[t]{2}{*}{ Kodlar } & \multicolumn{2}{|c|}{ Ölçütler } & \multirow[t]{2}{*}{ Destekleyici Cümleler } \\
\hline & & Evet & Hayır & \\
\hline \multirow{3}{*}{ 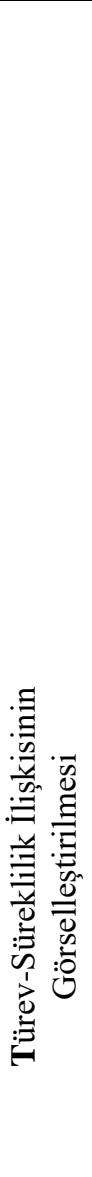 } & $\begin{array}{l}\text { Fonksiyonun } \\
\text { sürekli olduğu } \\
\text { noktada türevli } \\
\text { olması }\end{array}$ & $\begin{array}{c}\ddot{\mathrm{O}}_{1} \ddot{\mathrm{O}}_{2} \\
\ddot{\mathrm{O}}_{4}\end{array}$ & $\ddot{\mathrm{O}}_{3}$ & $\begin{array}{l}\text { Bir } f(x) \text { fonksiyonunun bir noktada önce sağ } \\
\text { ve sol limit dĕgerlerine bakılır. Bulunan bu } \\
\text { değerler birbirine eşit ve fonksiyonun o } \\
\text { noktadaki değeri de bu sağ-sol limit } \\
\text { değerine eşitse fonksiyon o noktada } \\
\text { süreklidir. Ancak bu türevli olmast için } \\
\text { yetmez. Aynı noktada săgdan ve soldan } \\
\text { türevlere bakllır. Sağ ve sol türev değerleri } \\
\text { birbirine eşit olduğunda fonksiyon o } \\
\text { noktada türevli olur }\left(\ddot{O}_{1}\right)\end{array}$ \\
\hline & $\begin{array}{l}\text { Fonksiyonun sürekli } \\
\text { olduğu noktada } \\
\text { türevli olmaması }\end{array}$ & $\begin{array}{c}\ddot{\mathrm{O}}_{1} \\
\ddot{\mathrm{O}}_{2} \ddot{\mathrm{O}}_{3}\end{array}$ & $\mathrm{O}_{4}$ & $\begin{array}{l}\text { Şimdi bir } f(x)=|x-2| \text { fonksiyonu düşünelim. } \\
\text { Yani doğrusal fonksiyonların kırllmış } \\
\text { hallerinden. Fonksiyonun } x=2 \text { noktasında } \\
\text { sürekliliğine engel olan hiçbir şey yokken } \\
\text { fonksiyon bu noktada türevsizdir. Çünkü o } \\
\text { noktada soldan eğimle sağdan eğim } \\
\text { birbirinden farklı olduğu için. Yani sol türev } \\
\text { ve sağ türev değerleri birbirinden farklıdır. } \\
\text { Dolaylstyla türevsizdir }\left(\ddot{O}_{3}\right)\end{array}$ \\
\hline & $\begin{array}{l}\text { Fonksiyonun } \\
\text { sürekli olmadığı } \\
\text { noktada türevli } \\
\text { olmaması }\end{array}$ & $\begin{array}{c}\ddot{\mathrm{O}}_{1} \mathrm{O}_{2} \\
\ddot{\mathrm{O}}_{4}\end{array}$ & $\ddot{\mathrm{O}}_{3}$ & $\begin{array}{l}x \text { ekseni üzerinde bir "a" noktası alalım. } \\
\text { Bu a noktasının görüntüsü c olsun. } \\
\text { Fonksiyonun limitine săgdan baktı̆̆ımda } \\
\text { " } b \text { " değeri, limitine soldan baktı̆̆ımda ise } \\
\text { "d" değeri çlklyor. Fonksiyonun "a" } \\
\text { noktasındaki değeri limit değerlerine ve bu } \\
\text { değerler de birbirlerine eşit olmuyor. O } \\
\text { nedenle fonksiyon "a" noktasında } \\
\text { süreksizdir. Süreksiz olduğu için de aynı } \\
\text { noktada türevsizdir }\left(\ddot{O}_{4}\right)\end{array}$ \\
\hline
\end{tabular}




\begin{tabular}{|c|c|c|c|}
\hline \multirow{4}{*}{$\begin{array}{l}\text { Fonksiyonun türevli } \\
\text { olduğu noktada } \\
\text { sürekli olması }\end{array}$} & \multirow{4}{*}{\multicolumn{2}{|c|}{$\begin{array}{c}\ddot{\mathrm{O}}_{1} \ddot{\mathrm{O}}_{2} \\
\ddot{\mathrm{O}}_{4}\end{array}$}} & $\begin{array}{l}\text { Ş̈̈yle dü̈sünelim. } f(x) \text { fonksiyonunun bir } \\
x=x_{0} \in[\mathrm{a}, \mathrm{b}] \text { noktasinda türevli olduğunu } \\
\text { düşünelim. Bu durumda sürekli olduğınu şu } \\
\text { şekilde yazılabiliriz }\left(\ddot{O}_{2}\right) \text { : }\end{array}$ \\
\hline & & & $\begin{array}{c}\lim _{x \rightarrow x_{0}} g(x)=f^{\prime}\left(x_{0}\right) \\
\lim _{x \rightarrow x_{0}} f(x)=\lim _{x \rightarrow x_{0}} f^{\prime}\left(x_{0}\right)+\lim _{x \rightarrow x_{0}} f\left(x-x_{0}\right)_{\times g(x)} \\
\lim _{x \rightarrow x_{0}} f(x)=f^{\prime}\left(x_{0}\right)+\lim _{x \rightarrow x_{0}} f\left(x-x_{0}\right)_{\times} \lim _{x \rightarrow x_{0}} g(x)\end{array}$ \\
\hline & & & $\lim _{x \rightarrow x} f(x)=f^{\prime}\left(x_{0}\right)+0 \times g\left(x_{0}\right)$ \\
\hline & & & $\lim f(x)=f^{\prime}\left(x_{0}\right)$ \\
\hline
\end{tabular}

Tablo 7 incelendiğinde Ö$_{1}$ ve Ö$_{2}$ 'nin türev-süreklilik ilişkisinin görselleştirilmesi sürecindeki açıklamalarının yeterli olduğu söylenebilir. Ancak Ö${ }_{3}$ ve Ö 4 'ün türev-süreklilik ilişkisinin görselleştirilmesine yönelik çizimlerinin ve yaptıkları açıklamaların yeterli olmadığı söylenebilir. Ö 3 türev-süreklilik arasındaki ilişkiyi anlatırken fonksiyonun sürekli olduğu noktada türevli olmayacağına yönelik çizim yapmasına rağmen fonksiyonun sürekli olduğu noktada türevli olabileceğine, sürekli olmadığı noktada türevli olmayacağına ve türevli olduğu noktada sürekli olmasına yönelik herhangi bir çizim yapmamış ve bu durumu destekleyici bir açıklamada bulunmamıştır. Ö$_{4}$ öğretmeni ise türev-süreklilik arasındaki ilişkiyi anlatırken fonksiyonun sürekli olduğu noktada türevli olmayacağına yönelik herhangi bir çizim yapmamış ve bu durumu destekleyici bir açıklamada bulunmamıştır.

\section{Sonuç, Tartışma ve Öneriler}

Lise matematik öğretmenlerinin türev kavramına yönelik tanımları ayrıntılı incelendiğinde tüm öğretmenlerin türeve yönelik gerekli ancak yeterli olmayan tanımlar yaptıkları görülmüştür. $\ddot{\mathrm{O}}_{2}, \mathrm{Ö}_{3}$ ve Ö${ }_{4}^{\prime}$ 'e nispeten daha yeterli bir tanımda bulunan Ö 1 türevin tanımını yaparken fonksiyonun belirli bir aralıkta tanımlı olduğunu belirtmiş ancak tanım-görüntü kümelerine ve türevi aranacak $x_{0}$ noktasının açık aralığın bir elemanı olmasına dikkat etmemiştir. $\ddot{O}_{2}$ ise türevin 
tanımını sembolik olarak göstermesine rağmen fonksiyonun tanımgörüntü kümelerine, fonksiyonun tanımlı olduğu açık aralığa, türevi aranacak $\mathrm{x}_{\mathrm{o}}$ noktasının bu açık aralığın bir elemanı olmasına ve türevin cebirsel tanımı yoluyla bulunan limit değerinin $\mathrm{x}=\mathrm{x}_{0}$ noktasındaki türeve karşılık geldiğine değinmemiştir. Oysaki Yağc1 (1999) ile Kadığlu ve Kamalı (2005)'e göre türev kavramı sembolik olarak şu şekilde tanımlamıştır:

$f: R \rightarrow R$ ve $(a, b)$ açık aralı̆̆ında tanıml bir fonksiyon, $x_{l} \in(a, b)$
olmak üzere $\quad \lim _{x \rightarrow x_{1}} \frac{f(x)-f\left(x_{1}\right)}{x-x_{1}}=f^{\prime}\left(x_{1}\right)$ ifadesindeki limit değeri bir reel saylysa $f(x)$ fonksiyonunun $x=x_{I}$ noktasindaki türevi bu reel saylya eşittir.

Yapılan bu tanımda fonksiyonun; tanım-görüntü kümeleri ile tanımlı olduğu açık aralık belirtilmiş, türevi aranacak noktanın açık aralığın bir elemanı olduğu ifade edilmiş ve türevin cebirsel tanımı yoluyla bulunan limit değerinin $\mathrm{x}=\mathrm{x}_{1}$ noktasındaki türeve karşıllı geldiği açıklanmıştır. Öğretmenlerden $\ddot{O}_{3}$ ve $\ddot{O}_{4}$ türevi aranacak özel bir $\mathrm{x}_{0}$ noktasından ziyade herhangi bir $\mathrm{x}$ bağımsız değişkeni için türevin arand1ğ 1 cebirsel gösterimi belirtmiştir. $\ddot{\mathrm{O}}_{3}$ ve $\ddot{O}_{4}$ fonksiyonun tanım-görüntü kümelerini belirtmemiş ve türevin cebirsel tanımını yazarken h artımının nasıl kullanıldığını ifade etmemiştir. Ayrıca Ö 4 öğretmeni $\mathrm{h}$ artımını sıfıra yaklaştırması gerekirken $\mathrm{x}$ bağımsız değişkenini $\mathrm{h}$ artımına yaklaştırarak türevin cebirsel tanımını yanlış belirtmiştir. Oysaki Demir (2014)'e göre fonksiyonun herhangi bir x bağımsız değişken noktasındaki türevi şu şekilde açıklanmıştır:

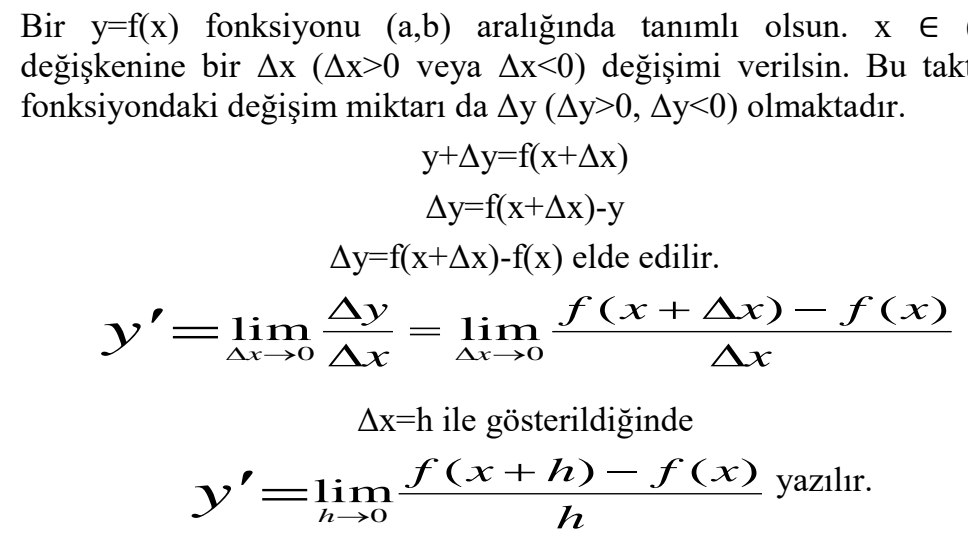


Yapılan bu tanımda fonksiyonun belirli bir aralıkta tanımlı olduğu ve bağımsız değişkenin aynı aralığın bir elemanı olduğu verilmiştir. Fonksiyonun herhangi bir noktadaki türevinin değeri bulunmadan önce değişkene verilen değişim miktarı, fonksiyondaki değişim miktarına oranlamıştır. Daha sonra değişkendeki değişimin sıfira yaklaşma durumu düşünülerek o durumda varolan limit, fonksiyonun türevi olarak açıklanmıştır. Hatta $\Delta \mathrm{x}$ ifadesi h artımına eşitlendikten sonra fonksiyonun herhangi bir $\mathrm{x}$ bağımsız değişken noktasındaki türevinin cebirsel tanımı belirtilmiştir. Yapılan tanımlardan hareketle öğretmenlerin türev kavramının tanımına yönelik yeterli konu alanı bilgisine sahip olmadıkları söylenebilir. İlgili alanyazında da öğretmenlerin ve öğretmen adaylarının türev kavramını tanımlarken zorluk yaşadıklarına dair sonuçlar yer almaktadır (Orton, 1983; Zandieh, 1997).

Açıkyıldız (2013)'ün öğretmen adaylarının türev-limit ilişkisine yönelik yüzeysel ve işlemsel bilgiye sahip olduklarına yönelik bulgusu ile türev-limit arasındaki ilişki cebirsel olarak belirtilmesine rağmen formül altındaki kavramsal yapı açıklanırken zorluk yaşandığı şeklindeki bulgusu araştırmanın bu bulgusuyla örtüşmüştür. Açıkyıldız (2013)'ün çalışmasında çoğu öğretmen adayı türevi kendi cümleleriyle yanlış şekilde açıklamıştır. Öğretmen adaylarından bazıları türevi "bir eğrinin üzerindeki herhangi bir noktadaki eğim" şeklinde açıklamıştır. Benzer açıklama bu araştırmada da söz konusudur. Ön görüşmelerde kendisini türev konusunda yetersiz bulan ve en az hizmet süresine sahip fen edebiyat fakültesi mezunu $\mathrm{Ö}_{4}$, türevi "bir eğrinin bir noktadaki eğimi” şeklinde açıklamıştır. Oysaki türev, bir eğrinin bir noktadaki teğetinin eğimi şeklinde ifade edilmektedir (Zandieh, 2000). Ubuz (1996)'a göre yanlış yapılan tanımlamaların nedeni tanım içeriklerinin anlaşılmaması ve tanımın bütün olarak özümsenmemesidir. Bununla birlikte Ubuz (1996) ile Amoah ve Laridon (2004) öğrencilerin analizde çoklu temsiller arasındaki geçişlerde sağlıklı kavramsal bağlantılar kuramadıklarını belirtmiştir.

Öğretmenlerin türev kavramına yönelik günlük hayattan verdikleri örnekler ayrıntılı incelendiğinde bu örneklerin anlık değişim, değişim hızı ve değişim oranı gibi prototip örneklerle sınırlandığı görülmüştür. Verilen bu örneklerin tümünün alan öğretim 
kitaplarında (Balcı, 1999; Çetinkaya vd., 2013; Demir, 2014; Thomas vd., 2009, Yağc1, 2014) ve lise matematik ders kitaplarında (Aydın \& Erbaş, 2011; Çakımcı \& Kabasakal, 2016; Çarhoğlu \& Gezmiş, 2015; Gürler \& Y1lmaz, 2016) yer aldığ1 tespit edilmiştir. Ancak Ö $1, \ddot{O}_{2}$ ve Ö 4 'ün "anlık değişim” ve "değişim oranı" örnekleri ve Ö ${ }_{1}^{\prime}$ 'in “değişim hızı" örneğinin eksik örnekler olduğu söylenebilir. Çünkü $y=f(x)$ denklemine sahip bir f fonksiyonunun $\mathrm{x}_{\mathrm{o}}$ noktasındaki anlık değişim oranı ya da anlık değişim hızı fonksiyonun o noktadaki türevi olarak tanımlandığından (Çetinkaya vd., 2013) öğretmenler tarafından verilen günlük hayat örneklerinin de kavramsal olarak türevin tam karşılığ 1 olmadığ1 görülmektedir. Öte yandan sadece Ö' 'ün verdiği bir örneğin prototip olmayan örnek olduğu belirlenmiştir. Açıkyıldız (2013) ile Vinner (1992)'nin öğretmen adaylarının türev kavramına yönelik günlük hayattan verdikleri örneklerin prototip örnekler olduğu bulgusu araştırmanın bu bulgusuyla örtüşmektedir.

Prototip örneklerin kavram imajı oluşturmada etkili olduğu söylenebilir (Fischbein, 1993; Hershkowitz, 1990). Ancak bir kavram öğrenilirken sadece prototip örneklerle öğretimde bulunmak öğrenenlerin sınırlı kavram imajı oluşturmasına neden olmaktadır (Tsamir, Tirosh \& Leverson, 2008). Tall ve Vinner (1981)'e göre bir kavram öğrenilirken o kavrama yönelik prototip olmayan, zengin örneklendirme yapılmalıdır. Ancak bazen bir kavrama yönelik örnek sayısını arttırmak öğrenenler üzerinde yanlış kavram imajlarının oluşmasına neden olabilmektedir (Gökkurt, 2014). Bu nedenle öğrenenlerin, zihinlerinde doğru kavram imajını oluşturması için kavramın özelliklerini yansitan en uygun örneklerin tercih edilmesi gerekir (Weber, Porter \& Housman, 2008).

Öğretmenlerin türevin tanımına yönelik çizim örnekleri ayrıntılı incelendiğinde tüm çizim örneklerinin lise matematik ders kitaplarında (Çakımcı \& Kabasakal, 2016; Çarhoğlu \& Gezmiş, 2015) ya da alandaki matematik öğretim kitaplarında (Balc1, 1999; Kadığlu \& Kamalı, 2005; Thomas vd., 2009; Yağc1, 2014) yer alan prototip çizimler olduğu görülmüştür. Ö${ }_{1}$ ve $\mathrm{O}_{2}$ 'nin yaptığı çizimlerin türevdeğişim oranı ilişkisine yönelik, $\ddot{O}_{3}$ ve Ö$_{4}$ ' ${ }^{\prime}$ n yaptığı çizimlerin ise türev-eğim ilişkisine yönelik çizimler olduğu tespit edilmiştir. Buna göre Ö 1 ve Ö 2 'nin zihinlerinde türev-değişim oranı ilişkisine yönelik, $\ddot{\mathrm{O}}_{3}$ ve Ö$_{4}$ 'ün zihinlerinde ise türev-eğim ilişkisine yönelik kavram 
imajına sahip oldukları söylenebilir. Öğretmenlerle yapılan görüşmelerde sadece $\mathrm{Ö}_{1}$ türevin tanımının çizimini gerekli ve yeterli düzeyde açıklamıştır. Buna karşın $\ddot{O}_{2}, \ddot{O}_{3}$ ve $\ddot{O}_{4}$ türevin tanımının görselleştirilmesine yönelik gerekli ancak yetersiz açıklamalarda bulunmuştur.

Öğretmenlerin türev-süreklilik ilişkisine yönelik görüşleri ayrıntılı incelendiğinde $\ddot{O}_{1}$ ve $\ddot{O}_{2}$ tarafından yapılan açıklamalarla verilen örneklerin yeterli düzeyde olduğu söylenebilir. Bu sayede $\mathrm{O}_{1}$ ve $\ddot{O}_{2}$ türev-süreklilik arasındaki ilişkiyi açıklayarak bu ilişkiye yönelik doğru çizim örneklerinde bulunmuştur. Bu öğretmenler türevsüreklilik ilişkisine yönelik lise matematik ders kitaplarındaki (Aydın \& Erbaş, 2011; Çakımcı \& Kabasakal, 2016; Çarhoğlu \& Gezmiş, 2015) örneklere benzer formatta prototip örnekler vermiştir. Hatta $\ddot{O}_{2}$ türev-süreklilik ilişkisine yönelik prototip olmayan örnekler de vermiştir.

Öğretmenlerden $\ddot{O}_{3}$ ve Ö$_{4}$ ise türev-süreklilik ilişkisine yönelik gerekli ancak yetersiz kritik özellikler ifade etmiştir. Benzer durum aynı öğretmenlerin türev-süreklilik ilişkisine yönelik yapılan çizimlerde de görülmüştür. Öğretmenlerin türev-süreklilik ilişkisine yönelik çizim örnekleri lise matematik ders kitaplarındaki (Aydın \& Erbaş, 2011; Çakımcı \& Kabasakal, 2016; Çarhoğlu \& Gezmiş, 2015) ve alan öğretim kitaplarındaki (Balc1, 1999; Çetinkaya vd., 2013; Demir, 2014; Thomas vd., 2009, Yağc1, 2014) prototip örneklerle sınırlandırılmıştır.

Öğretmenlerden $\ddot{O}_{3}$ ve Ö 4 , Balc1 (1999), Çakımcı ve Kabasakal (2016) ile Yağcı (2014)'ün çalışmalarındaki türev-süreklilik ilişkisini yansıtan kritik özellikleri eksik belirtmiştir. Araştırmanın bu bulgusu Viholainen (2006)'nın öğretmen adaylarının türev-süreklilik ilişkisini yetersiz açıkladıkları şeklindeki bulguyla örtüşürken Açıkyıldız (2013)'ın fonksiyonun sürekli olunan her noktada türevli olduğu şeklindeki bulgusuyla çelişmiştir. Açıkyıldız (2013)'ün çalışmasında öğretmen adayları sürekliliği fonksiyonun bir noktada türevli olması için yeterli koşul olarak düşündüklerinden fonksiyonun sürekli olduğu halde türevsiz olduğu kırılma noktalarını dikkate almamıştır. $\mathrm{Bu}$ nedenle öğretmen adayları, fonksiyonun sürekli olduğu her noktada türevli olması gerektiğini belirtmiştir. 
Tüm bu sonuçlara göre öğretmenlerin türevin tanımına, türevin tanımının görselleştirilmesine ve türev-süreklilik arasındaki ilişkinin belirtilmesine yönelik konu alanı bilgilerinin yeterli olmadığ görülmüştür. Ayrıca öğretmenlerin türevin tanımı, türevin tanımının görselleştirilmesi ve türeve günlük hayattan örnekler verilmesi konusunda bazı zorluklara sahip oldukları tespit edilmiştir. Öğretmenlerin türeve yönelik konu alanı bilgileri kendi aralarında karşılaştırıldığında Ö ${ }_{1}$ 'in türeve yönelik konu alanı bilgisinin en iyi düzeyde olduğu, hizmet süresi en fazla olan $\ddot{O}_{3}$ ile hizmet süresi en az olan Ö${ }_{4}$ 'ün ise türeve yönelik konu alanı bilgisinin en kötü düzeyde olduğu belirlenmiştir. Buna göre öğretmenlerin konu alanı bilgilerinin belirlenmesinde mesleki deneyim kriterinin çok etkili olmadığ söylenebilir.

Konu alanı bilgileri sırasıyla en iyi ve en kötü düzeyde olan Ö ve $\mathrm{O}_{4}$ fen edebiyat fakültesi mezunlarıdır. Mesleki deneyim kriterine benzer şekilde mezun olunan fakültenin de ögretmenlerin konu alanı bilgi düzeylerinin belirlenmesinde çok etkili olmadığı söylenebilir. Konu alanı bilgisi en iyi düzeyde olan $\mathrm{O}_{1}$ ön görüşmeler sonunda türev konusunda kendisini yeterli bulduğunu ve lisans dönemindeki matematik ders başarısının çok iyi olduğunu ifade etmiştir. Ö ${ }_{1}$ in türeve yönelik en iyi düzeyde konu alanı bilgisine sahip olmasının nedeni lisans eğitiminde elde ettiği başarıları öğretmenlik hayatına da yansıtmış olmasından kaynaklanabilir. Konu alanı bilgisi en kötü düzeyde olan Ö$_{4}$ ile yapılan ön görüşmelerde Ö$_{4}$ türev konusunda kendisini yeterli bulmadığını açıklamıştır. Araştırmadan elde edilen sonuçlar da dikkate alındığında $\mathrm{O}_{4}$ 'ün türeve yönelik konu alanı bilgi düzeyindeki yetersizliğinin farkında olduğu söylenebilir. Ö${ }_{4}^{\prime}$ 'ün konu alanı bilgisindeki yetersizliğinin nedeni 12 .sınıfta daha az matematik dersine girmiş olmasından da kaynaklanabilir. Ö 3 öğretmeniyle yapılan ön görüşmelerde, $\mathrm{O}_{3}$ türev konusunda kendisini yeterli bulduğunu açıklamıştır. Ancak araştırma sonuçları da dikkate alındığında Ö̈'ün türeve yönelik konu alanı bilgisindeki yetersizliğinin farkında olmadığ 1 söylenebilir. Bununla birlikte konu alanı bilgisindeki yetersizliğin nedeni olarak $\mathrm{O}_{3}{ }^{\prime}$ ün matematik dersinde kendisini yeterli gördüğü halde konular üzerinde fazla çaba harcamaması gösterilebilir. Ö${ }_{1}$ 'den sonra en iyi düzeyde konu alanı bilgisine sahip olan $\mathrm{O}_{2}$ ile yapılan ön görüşmeler sonunda, $\mathrm{O}_{2}$ türev 
konusunda kendisini yeterli bulduğunu ve lisans döneminde matematik derslerindeki başarısının orta düzeyde olduğu belirtmiştir. Ö${ }_{2}$ 'nin türev-süreklilik ilişkisine yönelik alan öğretim kitapları dişından prototip olmayan örnekler vermesinin ve fonksiyonun türevli olduğu noktada sürekli olmasıyla ilgili ispatının sebebi matematik alanında master yapmış olmasından kaynaklanabilir.

Araştırmadan elde edilen sonuçlar birlikte değerlendirildiğinde 12.sınıflarda öğretim yapan matematik öğretmenlerinin türevin tanımını sembolik ve sözel olarak ifade etme, türeve günlük hayattan örnekler verme ve türevin tanımını görselleştirme noktasında problem yaşadıklarını göstermektedir. Ayrıca bu sonuçlar, öğretmenlerin türevsüreklilik arasındaki ilişkiye yönelik geniş çaplı muhakeme yapmadıklarını da ortaya koymuştur. Araştırmadan elde edilen sonuçlardan hareketle lisans eğitimi sırasında analiz derslerindeki fonksiyon, limit, türev ve integral gibi temel konular işlenirken kullanılacak çoklu temsillerin, matematik öğretmenlerinin pedagojik alan bilgilerinin gelişimine katkı sağlayacağı düşünülmektedir. Çoklu temsiller sayesinde kavramların farklı yönlerinin görüldüğ̈ ve farklı temsiller arası dönüşümlerde kavramın daha kalıcı öğrenildiği bilindiğinden (O'Callaghan, 1998) grafiksel, sembolik, fiziksel ve sözel olarak tanımlanabilen türev kavramı değişik formlarda temsil edilebilir. Bunun yanı sıra yüksek öğretim düzeyindeki analiz derslerinde türev tanımı anlatılırken görselleştirme yoluyla teknoloji kullanılarak öğretim sağlanabilir. Nitekim lise düzeyinde öğrencilere hitap eden öğretmenlerin türev konusunda önce kendilerinin gerekli donanıma sahip olması gerekir. $\mathrm{Bu}$ nedenle öğretmenler zümre toplantılarında belirli aralıklarla bir araya gelip türevin öğrencilere en doğru şekilde nasıl anlatılacağı noktasında fikir alışverişinde bulunabilirler ve türev konusunda yaşanılan zorlukların giderilmesi noktasında çözüm önerileri sunabilirler.

Limit, süreklilik ve türev kavramlarının anlaşılmasında fonksiyon kavramının önemli bir etkiye sahip olduğu bilindiğinden (Ferrini Mundi \& Graham, 1991) öğretmenlerin önşartlılık ilkesine dikkat etmesi gerekir. Bu nedenle türev-süreklilik arasındaki ilişkinin eksiksiz ve doğru anlatılması için fonksiyon ve limit kavramları üzerinde yoğun şekilde durulmalıdır. Mevcut çalışma lise matematik öğretmenleriyle gerçekleştirildiğinden fonksiyon, limit, türevin 
uygulamaları, integral gibi konularda öğretmenlerin ve öğretmen adaylarının konu alanı bilgilerine yönelik nicel ve nitel araştırmalar yapılabilir. Öğretmenlerin türeve yönelik konu alanı bilgileri görüşme, gözlem ve döküman incelemesi gibi birden fazla nitel veri toplama aracı kullanılarak araştırılabilir. Öğretmenlerin türeve yönelik konu alanı bilgi düzeylerini arttırmak amacıyla düzey belirlendikten sonra mikroöğretim yoluyla daha kalıcı ve sağlıklı öğrenmeler gerçekleştirilebilir.

\section{Kaynaklar}

Akkoç, H., Yeşildere, S., \& Özmantar, F. (2007). Prospective mathematics teachers' pedagogical content knowledge of definite integral: The problem of limit process. In D. Küchemann (Ed.), Paper Presented at the British Society for Research into Learning Mathematics (pp. 7-12).

Alev, N., \& Karal, I.S. (2013). Fizik öğretmenlerinin elektrik ve manyetizma konularına ilişkin pedagojik alan bilgilerinin belirlenmesi. Mersin Üniversitesi Ĕ̈itim Fakültesi Dergisi, 9(2), 88-108.

Altaylı, D., Konyalığlu, A.C., Hızarc1, S., \& Kaplan, A. (2014). İlköğretim matematik öğretmen adaylarının üç boyutlu cisimlere ilişkin pedagojik alan bilgilerinin incelenmesi. Middle Eastern \& African Journal of Educational Research, 10, 4-24.

Amoah, V., \& Laridon, P. (2004). Using multiple representations to assess students' understanding of the derivative concept. BSRLM, 24(1), 1-6.

Arslan Kılcan, S. (2006). Illköğretim matematik öğretmenlerinin kesirlerle bölmeye ilişsin kavramsal bilgi düzeyleri. Yayınlanmamış yüksek lisans tezi, Abant İzzet Baysal Üniversitesi, Bolu, Türkiye.

Artigue, M. (1991). Analysis. In I.D. Tall \& S. Vinner (Eds.), Advanced mathematical thinking (pp. 167-198). Dordrecht: Kluwer Academics.

Aydın, N., \& Erbaş, K. (2011). Ortaöğretim matematik 12. Ankara: Aydın Yayınları.

Balc1, M. (1999). Matematik analiz. Ankara: Balcı Yayıları.

Ball, D.L., \& McDiarmid, G.W. (1990). The subject matter preparation of teachers. In R. Houston (Eds.), Handbook for research on teacher education (pp. 437449). New York: Macmillan.

Batur, Z., \& Balcı, S. (2013). Türkçe öğretmen adaylarının pedagojik alan bilgilerinin incelenmesi. Adlyaman Üniversitesi Sosyal Bilimler Enstitüsü Dergisi, 6(11), 21-43.

Bennett, S.N., \& Turner-Bisset, R.A. (1993). Case studies in learning to teach. In S.N. Bennett \& C.G. Carre (Eds.). Learning to teach (pp. 165-190). London and New York: Routledge. 
Bezuindenhout, J. (1998). First year university students' understanding of rate of change. International Journal of Mathematical Education in Science and Technology, 29, 389-399.

Bingölbali, E. (2013). Türev kavramına ilişkin öğrenme zorlukları ve kavramsal anlama için öneriler. In M.F. Özmantar, E. Bingölbali \& H. Akkoç (Ed.), Matematiksel kavram yanılgıları ve çözüm önerileri (s. 223-255). Ankara: Pegem Akademi.

Burton, M. (1989). The effect of prior calculus experience in "introductory" college calculus. American Mathematical Monthly, 96, 350-354.

Canbazoğlu, S., Demirelli, H., \& Kavak, N. (2010). Fen bilgisi öğretmen adaylarının maddenin tanecikli yapısı ünitesine ait konu alanı bilgileri ile pedagojik alan bilgileri arasındaki ilişkilerin incelenmesi. Ilköğretim Online, 9(1), 275-291.

Cohen, D.K., McLaughlin, M.W., \& Talbert, J.E. (1993). Teaching for understanding: Challenges for policy and practice. San Francisco: JosseyBoss.

Çakmak, Z., Konyalığlu, A.C., \& Işık, A. (2014). İlköğretim matematik öğretmen adaylarının üç boyutlu cisimlere ilişkin konu alanı bilgilerinin incelenmesi. Middle Eastern \& African Journal of Educational Research, 8, 28-44.

Çakımcı, T., \& Kabasakal, V. (2016). Ortaöğretim ileri düzey matematik 12. Ankara: Nova Yayıncılık.

Çarhoğlu, M.A., \& Gezmiş, A.T. (2015). Ortaöğretim matematik 12 ders kitabı. Ankara: Ada Matbaacılık.

Çepni, S. (2012). Araştırma ve proje çalışmalarına giriş (6.Basım). Trabzon: Celepler Matbaacılık.

Çetinkaya, B., Erbaş, A.K., \& Alacalı, C. (2013). Değişim oranı olarak türev ve tarihsel gelişimi. In İ.Ö. Zembat, M.F. Özmantar, E. Bingölbali, H. Şandır \& A. Delice (Ed.), Tanımları ve tarihsel gelişimleriyle matematiksel kavramlar (ss. 529-555). Ankara: Pegem Akademi.

Dani, D.E. (2004). The impact of content and pedagogy courses on science teachers' pedagogical content knowledge. Unpublished doctoral dissertation, University of Cincinnati, Cincinnati, USA.

Daymon, C., \& Holloway, I. (2003).Qualitative research methods in public relations and marketing communications. London: Routledge.

Demir, H. (2014). Teori ve problemleriyle Analiz-1. Ankara: Pegem Akademi.

Duru, A. (2006). Bir fonksiyon ve onun türevi arasındaki ilişkiyi anlamada karşılaşılan zorluklar. Yayınlanmamış doktora tezi, Atatürk Üniversitesi, Erzurum, Türkiye.

Ekiz, D. (2009). Bilimsel araştırma yöntemleri. Ankara: Anı Yayıncılık.

Erdem, M. (2005). Öğretmenlik mesleğine giriş. İstanbul: Epsilon Yayıncılık. 
Ferrini Mundy, J., \& Graham, K.G. (1991). An overview of the calculus reform effort: Issues for learning, teaching and curriculum development. American Mathematical Monthly, 98(7), 627-635.

Fischbein, E. (1993). The theory of figural concept. Educational Studies in Mathematics, 24(2), 139-162.

Gess Newsome, J. (1999). Pedagogical content knowledge: an introduction and orientation. In Gess Newsome, J. \& Lederman, N.G. (Eds.), Examining pedagogical content knowledge: The construct and its implications for science education (pp. 3-17). London: Kluwer Academics.

Glesne, C. (2013). Nitel araştırmaya giriş. Ankara: Anı Yayıncılık.

Gökbulut, Y. (2010). Sinıf ögretmeni adaylarının geometrik cisimler konusundaki pedagojik alan bilgileri. Yayınlanmamış doktora tezi, Gazi Üniversitesi, Ankara, Türkiye.

Gökkurt, B. (2014). Ortaokul matematik öğretmenlerinin geometrik cisimler konusuna ilişkin pedagojik alan bilgilerinin incelenmesi. Yayınlanmamış doktora tezi, Atatürk Üniversitesi, Erzurum, Türkiye.

Gökkurt, B., Şahin, Ö., \& Soylu, Y. (2012). Matematik öğretmenlerinin matematiksel alan bilgileri ile pedagojik alan bilgileri arasındaki ilişkinin incelenmesi. The Journal of Academic Social Science Studies, 5(8), 9971012.

Gökkurt, B., Şahin, Ö., Soylu, Y., \& Doğan, Y. (2015). Öğretmen adaylarının geometrik cisimler konusuna ilişkin öğretmen hatalarına yönelik pedagojik alan bilgileri. Illkögretim Online, 14(1), 55-71.

Grossman, P.L. (1990). The making of a teacher: Teacher knowledge and teacher education. New York: Teachers College Press.

Gürler, C., \& Y1lmaz, N. (2016). Matematik 12 temel düzey ders kitabı. Ankara: Aydin Yayınları.

Halim, L., \& Meerah, S.M. (2002). Science trainee teachers' pedagogical content knowledge and its influence on physics teaching. Research in Science and Technological Education, 20(2), 215-226.

Hawkins, W.J. (2012). An investigation of primary teachers' pedagogical content knowledge when teaching measurement to years three and four. Paper Presented at the $12^{\text {th }}$ International Congress on Mathematical Education, Seoul, South Korea.

Hershkowitz, R. (1990). Psychological aspects of learning geometry. In P. Nesher \& J. Kilpatrick (Eds.), Mathematics and cognition. Cambridge: Cambridge University Press.

Hiebert, J., \& Lefevre, P. (1986). Conceptual and procedural knowledge in mathematics: An introductory analysis. In J. Hiebert (Eds.), Conceptual and procedural knowledge: The case of mathematics (pp. 1-27). Hillsdale, NJ: Erlbaum. 
Işıksal, M. (2006). A study on pre-service elementary mathematics teachers' subject matter knowledge and pedagogical content knowledge regarding the multiplication and division of fractions. Unpublished doctoral dissertation, Middle East of Technical University, Ankara, Turkey.

James, M.D. (1995). Should calculus be taught in high school and if so how should it be taught?.http://jwilson.coe.uga.edu/EMT705/EMT705.James.html internet adresinden 09, 02, 2016 tarihinde edinilmiştir.

Kadığlu, E., \& Kamalı, M. (2009). Genel matematik. Erzurum: Kültür Eğitim Vakfi Yayınevi.

Käpyla, M., Heikkinen, J.P., \& Asunta, T. (2009). Influence of content knowledge on pedagogical content knowledge: The case of teaching photosynthesis and plant growth. International Journal of Science Education, 31(10), 1395-1415.

Krauss, S., Baumert, J., \& Blum, W. (2008). Secondary mathematics teachers' pedagogical content knowledge and content knowledge: validation of the COACTIV construct. ZDM Mathematics Education, 40, 873-892.

Konyalığlu, A.C. (2003). Üniversite düzeyinde vektör uzaylarl konusundaki kavramların anlaşılmasında görselleştirme yaklaşımının etkinliğinin incelenmesi. Yayınlanmamış doktora tezi, Atatürk Üniversitesi, Erzurum, Türkiye.

Lannin, J.K., Webb, M., Chval, K., Arbaugh, F., Hicks, S., Taylor, C., \& Bruton, R. (2013). The development of beginning mathematics teacher pedagogical content knowledge. Journal of Mathematics Teacher Education, 16(6), $403-$ 426.

Marks, R. (1990). Pedagogical content knowledge: From a mathematical case to a modified conception. Journal of Teacher Education, 41, 3-11.

Marvasti, A.B. (2004). Qualitative research in sociology. London: Sage Publication.

Miles, M.B., \& Huberman, M.A. (1994). An expanded sourcebook qualitative data analysis. London: Sage Publication.

O'Callaghan, B.R. (1998). Computer-intensive algebra and students' conceptual knowledge of functions. Journal for Research in Mathematics Education, 29(1), 21-40.

Orton, A. (1983). Student's understanding of differentiation. Educational Studies in Mathematics, 14(3), 235-250.

Patton, M. (1990). Qualitative evaluation and research methods. Beverly Hills, CA: Sage Publication.

Roberts, P., \& Priest, H. (2006). Reliability and validity in research. Nursing Standard, 20, 41-45.

Shulman, L. (1987). Knowledge and teaching: foundation of the new reform. Harward Educational Review, 57(1), 1-21. 
Shulman, L. (1986). Paradigms and research programs in the study of teaching: a contemporary prespective. In M, Wittrock (Eds.), Handbook of Research on Teaching. New York: Macmillian Publishing Company.

Skemp, R. (1978). Relational understanding and instrumental understanding. Arithmetic Teacher, 26(3), 9-15.

Tall, D.O., \& Vinner, S. (1981). Concept image and concept definition in mathematics with special reference to limits and continuity. Educational Studies in Mathematics, 12(2), 151-169.

Tavşancıl, E., \& Aslan, E. (2001). İçerik analizi ve uygulama örnekleri. İstanbul: Epsilon Yayıncılık.

Thomas G.B., Weir M.D., Hass J., \& Giordano F.R. (2009). Thomas' calculus (11.Basım). (Çev: Recep Korkmaz). Boston: Pearson Education.

Tichá, M., \& Hošpesová, A. (2010). Problem posing and development of pedagogical content knowledge in pre-service teacher training. Paper presented at the CERME 6, (pp. 1941-1950), January 28th-February 1st, Lyon, France.

Tsamir, P., Tirosh, D., \& Levenson, E. (2008). Intuitive nonexamples: the case of triangles. Educational Studies in Mathematics, 69(2), 81-95.

Türnüklü, E. (2005). Matematik öğretmen adaylarının pedagojik alan bilgileri ile matematiksel alan bilgileri arasındaki ilişski. Eğitim Araştırmaları Dergisi, 5(21), 234-247.

Twycross, A., \& Shields, L. (2005). Validity and reliability-what's it all about?: Part 3 issues relating to qualitative studies. Pediatric Nursing, 17, 36.

Ubuz, B. (1996). Evaluating the impact of computers on the learning and teaching of calculus. Unpublished doctoral dissertation, University of Nottingham, Nottingham, United Kingdom.

Veal, W.R., Tippins, D.J., \& Bell, J. (1998).The evolution of pedagogical content knowledge in prospective secondary physics teachers. Paper Presented at the Annual Meeting of the National Association for Research in Science Teaching. San Diego CA, USA.

Viholainen, A. (2006). Why is a discontinuous function differentiable?. Paper Presented at the $30^{\text {th }}$ Conference of the International Group of the Psychology of Mathematics Education. (pp. 329-336). Prague, Czechia.

Viveros, K., \& Sacristan, A. (2002). College students' conceptual links between the continuity and the differentiability of a function. Paper Presented at the North American Chapter of the International Group for the Psychology of Mathematics Education (24 ${ }^{\text {th }}$ Athens, Georgia, October 26-29). 1-4, 350-360.

Vinner, S. (1992). The function concept as a prototype for problems in mathematics learning. In G. Harel \& E. Dubinsky (Eds.), The concept of a function: Aspects of epistemology and pedagogy (pp. 195-213). Washington, DC: Mathematical Association of America. 
Weber, K., Porter, M., \& Housman, D. (2008). Worked examples and conceptual usage in understanding mathematical concepts and proofs. In M.P. Carlson \& C. Rasmussen (Eds.), Making the connection: Research and teaching in undergraduate mathematics (pp. 245-252). Washington, DC: Mathematical Association of America.

Yağcı, M. (2014). My matematik 3. İzmir:Altın Nokta Yayınevi.

Yeşildere, S., \& Akkoç, H. (2010). Matematik öğretmen adaylarının sayı örüntülerine ilişkin pedagojik alan bilgilerinin konuya özel stratejiler bağlamında incelenmesi. Ondokuz Mayıs Üniversitesi Eğitim Fakültesi Dergisi, 29(1), 125-149.

Yıldırım, K. (2010). Nitel araştırmalarda niteliği artırma. Ilköğretim Online, 9(1), 79-92.

Yıldırım, A., \& Şimşek, H. (2013).Sosyal bilimlerde nitel araştırma yöntemleri (9.Basım). Ankara: Seçkin Yayıncılık.

Yıldız, N. (2006). Matematik eğitiminde türev ögrenimi ve öğretimi ile ilgili sorulmuş bazl etkin sorular ve cevapları hakkında öğrencilerin ve ögretim elemanlarının görüşleri üzerine bir fenomenografik çalışma. Yayınlanmamış yüksek lisans tezi, Gazi Üniversitesi, Ankara, Türkiye.

Y1lmaz, N.P. (2016). ICT student teachers' pedagogical content knowledge: A case study. Eurasia Journal of Mathematics, Science \& Technology Education, 12(1), 133-152.

Yin, R.K. (1994). Case study research: design and methods (2nd Edition). Beverly Hills, CA: Sage Publication.

Yusof, Y.M., \& Zakaria, E. (2010). Investigating secondary mathematics teachers' pedagogical content knowledge: A case study. Journal of Education and Sociology, 32-39.

Zandieh, M.J. (2000). A theoretical framework for analyzing student understanding of the concept of derivative. In E. Dubinsky, A. Schoenfeld \& J. Kaput (Eds.), Research in collegiate mathematics education IV (pp. 103-126). Providence, RI: American Mathematical Society.

Zandieh, M.J. (1997). The evolution of student understanding of the concept of derivative. Unpublished doctoral dissertation, Oregon State University, Corvallis, USA.

Zazkis, R., \& Leiken, R. (2008). Exemplifying definitions: A case of a square. Educational Studies in Mathematics, 69, 131-148. 
M. Duran, A. Kaplan / Ë̈ Ĕ̈itim Fakültesi Dergisi, $18-2$ (2016), 795-831

\section{Extended Summary}

\section{Purpose}

Unlike high school teachers, studies for pedagogical content knowledge were often examined with prospective mathematics teachers in the literature. In spite of taking course for the formation towards teaching profession and doing internship at schools during undergraduate education, prospective mathematics teachers do not gain experience sufficiently. Therefore, the informations obtained from the prospective mathematics teachers can't allow to be determined the pedagogical content knowledge in the context of subject matter knowledge of high school mathematics teachers. Thus, the present study was conducted with the teachers in the teaching profession in person and involved in the teaching process. The purpose of this study is to investigate high school mathematics teachers' pedagogical content knowledge in the context of subject matter knowledge on the definition of derivative, the visualization of the definition of derivative, and the relationship between derivative and continuity. The four sub-problems conformed with the overall purpose of this study are described as follows:

1. What are the efficacy perceptions of high school mathematics teachers for the subject matter knowledge on derivatives?

2. What are the levels of high school mathematics teachers to define derivative and give examples to derivatives from everyday life?

3. What are the levels of high school mathematics teachers to visualize the definition of derivatives?

4. What are the levels of high school mathematics teachers to explain the relationship between derivatives and continuity?

\section{$\operatorname{Method}(\mathbf{s})$}

The case study design of the qualitative research models was used in this research. The research was carried out in a small-scaled city of the Black Sea Region of Turkey during the fall semester of 2015-2016 academic terms. The participants of the research were four mathematics teachers working in public high schools connected to the ministry of national education. The maximum variation sampling of purposeful sampling method was used when determining the teachers to join the study. The data collection tool was a semi-structural interview protocol developed by the researchers. The studies examining derivatives and pedagogical content knowledge were considered in the development process of the interview protocol. The research data was analyzed by content analysis. The researchers considered the framework specified by Zazkis and Leiken (2008) and then expanded by Gokkurt (2014) in the identification process under categories and encodes of the data obtained defining derivatives, giving examples to derivatives, visualizing the definition of derivative and explaining the relationship between derivatives and continuity. 
M. Duran, A. Kaplan / Ë̈ Ĕ̈itim Fakültesi Dergisi, $18-2$ (2016), 795-831

\section{Results}

When the high school teachers' detailed definitions to derivatives were examining, all teachers had necessary but not sufficient definitions for derivatives. When the teachers' detailed examples to derivatives from everyday life were examining, these examples have prototype features such as instantaneous change, rate of change and exchange ratio. All given examples by the teachers are included in the field of academical instruction and mathematics education books. Howewer, the examples such as instantaneous change, rate of changegiven by $\mathrm{O}_{1}, \mathrm{O}_{2}$ and $\mathrm{O}_{4}$ teachers and again the examples such as exchange ratio given by $\mathrm{O}_{1}$ are incomplete and not fully accurate examples. On the other hand, it is just an example of a non prototype given by $\mathrm{O}_{3}$ teacher. When the teachers' detailed drawing examples for the definition of derivatives were examining, all examples drawn by the teachers are the prototype drawings included in the field of mathematics textbooks and academical instruction books. The drawings made by $\mathrm{O}_{1}$ and $\mathrm{O}_{2}$ teachers are related to the relationship between derivative and rate of change. The drawings made by $\mathrm{O}_{3}$ and $\mathrm{O}_{4}$ teachers are related to the relationship between derivative and slope. When the teachers' detailed views for the relationship between derivatives and continuity were examining, the statements made and the examples given by $\mathrm{O}_{1}$ and $\mathrm{O}_{2}$ teachers are at the sufficient level. Accordingly, $\mathrm{O}_{1}$ and $\mathrm{O}_{2}$ teachers explained the derivatives-continuity relationship and done the right drawing examples for this relationship. On the other hand, $\mathrm{O}_{3}$ and $\mathrm{O}_{4}$ teachers expressed necessary but insufficient critical features related to the derivatives-continuity relationship.

\section{Conclusions and Discussions}

The function has a significant impact in understanding the concepts of limit, continuity and derivatives. Teachers should pay attention to the preconditionality principle in explaining the issue. It should focus on the function and limit concepts intensively to tell without possibility of misconceptionsthe relationship between derivatives and continuity accurately. The present study was conducted with high school mathematics teachers. Hence, the qualitative and quantitative studies may be done related to the subject matter knowledges of the mathematics teachers and preservice mathematics teachers in the issues such as the function, limit, applications of derivatives and integration. The teachers' subject matter knowledges for derivatives may be investigated with the help of more data collection tools such as the interviews, observations and document review in qualitative studies. In order to increase the levels of the teachers' subject matter knowledges, more permanent learnings are carried out through micro teaching at the end of the final evaluation. 